\title{
Atomic Absorption Spectrum of Praseodymium (Pr I)
}

\section{Romuald Zalubas and Michael Wilson*}

\author{
(August 12, 1964)

\begin{abstract}
Absorption lines of $\operatorname{Pr}$ I were observed using a King furnace. A list of 3532 lines in the region from 1741 to $5839 \AA$ is presented.
\end{abstract}

An absorption spectrum is of great help in the analysis of a complex and line-rich spectrum. Therefore arrangements were made to obtain the absorption spectra of some rare earths at the Imperial College of Science and Technology in London. Absorption spectrograms of praseodymium, cerium, and erbium have been obtained. The plates were taken with a $3-\mathrm{m}$ normal incidence vacuum spectrograph [1]. ${ }^{1}$ 'This instrument has a Bausch and Lomb aluminized replica grating of 30,000 lines per inch, blazed at $1500 \AA$ in the first order. The plate factor is $2.7 \AA / \mathrm{mm}$. Ilford $\mathrm{Q} 2$ and Astr. III plates were used. For the region above $2400 \AA$ the spectrograph was not evacuated.

The absorption vessel used was a large King furnace [1] with the following modification: the praseodymium was vaporized in a 6 in. long, 1/2-in. bore tantalum tube clamped between the ends of the conventional graphite tubes. With a 40 KVA power supply feeding a current transformer capable of delivering $1300 \mathrm{~A}$ at $30 \mathrm{~V}$, it was possible to heat the tantalum tube to any temperature up to its melting point at around $3000{ }^{\circ} \mathrm{C}$. The advantage of the tantalum tube over graphite is that carbide formation is inhibited, thus enabling the vaporization of many materials which would otherwise react with hot graphite.

A constant flow of purified helium was maintained at about $8 \mathrm{~mm} \mathrm{Ho}$ pressure to ensure clean conditions in the King furnace. The temperature was measured with an optical pyrometer suitably calibrated to allow for the difference in emissivity between the tube and a blackbody.

The following three sources for the production of continuum radiation were used: (1) a pointolite lamp (i.e., an incandescent strip of tungsten); (2) a $16 \mathrm{~A}$ xenon arc in a quartz envelope; and (3) a $\mathrm{H}_{2}$ positive column discharge observed end-on. Quartz and quartz-lithium fluoride optical elements were employed in the system.

Absorption spectra at two different temperatures close to 1700 and $2000{ }^{\circ} \mathrm{C}$, respectively, were photo-

\footnotetext{
*Imperial College of Science and Technology, London, England.
}

${ }^{1}$ Figures in brackets indicate the literature references at the end of this paper. graphed in each spectral region to assist in the classification of lines arising from the lower energy levels. An iron arc was superposed for standards in the region above $3000 \AA$ while a copper hollow cathode was used in the region below $3000 \AA$.

These plates have been measured by Zalubas as part of the work on the description and analysis of Pr I being done at the National Bureau of Standards. A scanning comparator built at NBS [2] served for measuring the plates. The measurements were reduced by an electronic computer. In the region 1741 to $3000 \AA$ the superposed standards were used for calculation of wavelengths of absorption lines. In the region above $3000 \AA$ the superposed iron standards were used only for identification of those praseodymium absorption lines that had previously been observed in emission at NBS [3]. The wavelengths of absorption lines were then calculated using the accurately known Pr I emission wavelengths as internal standards. In the region 3000 to $5839 \AA$ all absorption lines are easily identifiable with Pr I emission lines. In the shorter wavelength region absorption lines are more numerous than emission lines. Resonance lines of Er, Cr, Ca, Dy, Ho, Cu, $\mathrm{Mg}, \mathrm{Na}$, and $\mathrm{Fe}$ were found as impurities and eliminated.

The wavelengths are tabulated in table 1 . The first column gives the wavelength in angstrom units. The second column contains intensities of lines estimated by eye on the absorption plates. The letter symbols are used to describe the character of the lines; c-complex, d-double, h-hazy, l-shaded to longer wavelength, s-shaded to shorter wavelength, w-wide, and bl-blended lines.

The wavelengths given in table 1 were obtained from one measurement of each line in absorption, at the $2000^{\circ} \mathrm{C}$ furnace temperature. Their values have been rounded off to two decimal places; in general they agree within $\pm 0.02 \AA$ with the values obtained from measurements of emission lines in the region above $3000 \AA$. Below $3000 \AA$, however, the wavelength accuracy is not exactly known, since shifts may occur when the copper standards are superposed; although an unlikely occurrence, this possibility could not be ruled out by a comparison with emission line wavelengths in the same region. 
Since iron and copper standards were superposed on absorption spectrograms, there are some regions where the lines were partly masked by iron and xenon emission lines or molecular bands, thus causing apparent wavelength shifts. Also, some lines which we observed in emission as self-reversed were completely masked on the absorption plates by superposed standards.

The above wavelength accuracy is sufficient for identification purposes in astronomical or spectrochemical analysis. For spectrum analysis, the emission line wavelengths derived from the plates taken with higher dispersion instruments are used. Using the absorption data, regularities in the spectrum of $\operatorname{Pr}$ I have already been discovered, and analysis of the Pr I spectrum is being continued at the National Bureau of Standards.
It is our pleasure to express our appreciation to C. H. Corliss for the generous assistance he has provided. We are indebted to W. R. S. Garton for suggesting the tantalum tube modification to the King furnace. We also thank Mrs. R. L. Peterson for her assistance in preparing table 1.

\section{References}

[1] W. R. S. Garton and K. Codling, Proc. Phys. Soc. (London) $\mathbf{7 5}, 87$ (1960)

[2] M. L. Kuder, J. Res. NBS 65C (Eng. and Instr.) No. 1, 1 (1961).

[3] R. Zalubas, unpublished data (1964). 
TABLE 1. - W avelengths and intensities of absorption lines of $\mathrm{Pr}$

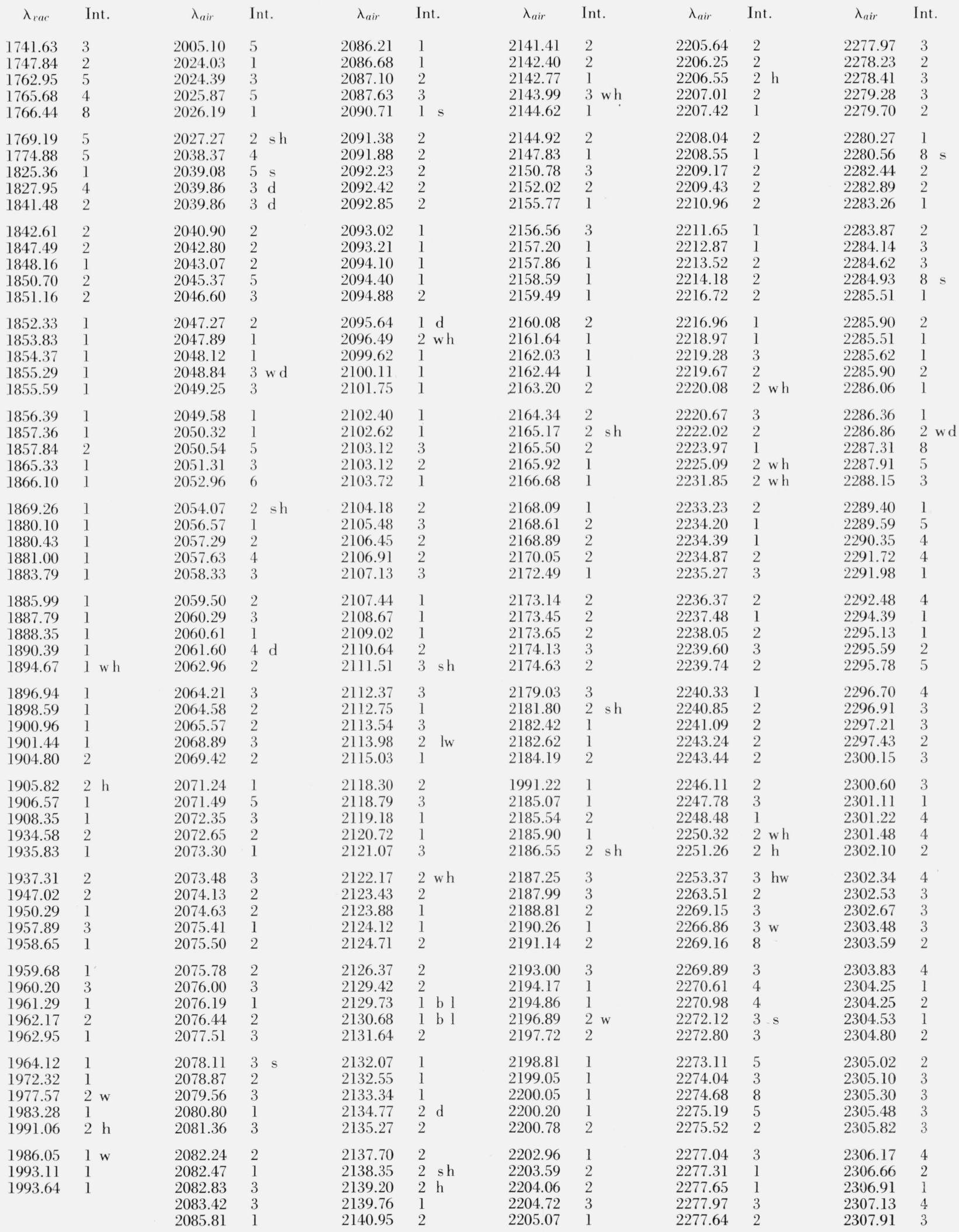


TABLE 1. - Wavelengths and intensities of absorption lines of $\mathrm{Pr}-$ Continued

\begin{tabular}{|c|c|c|c|c|c|c|c|c|c|c|c|}
\hline$\lambda_{\text {air }}$ & Int. & $\lambda_{\text {air }}$ & Int. & $\lambda_{\text {air }}$ & Int. & $\lambda_{\text {air }}$ & Int. & $\lambda_{\text {air }}$ & Int. & $\lambda_{\text {air }}$ & Int. \\
\hline 2308.07 & 2 & 2333.86 & 1 & 2358.91 & 3 & 2382.60 & 1 & 2405.08 & 3 & 2432.13 & 2 \\
\hline 2308.21 & 2 & 2334.14 & 8 & 2359.17 & 3 & 2382.83 & 1 & 2405.22 & 3 & 2432.44 & 2 \\
\hline 2308.72 & 2. & 2336.79 & 3 & 2359.69 & 1 & 2383.62 & 3 & 2405.40 & 1 & 2433.06 & 2 \\
\hline 2309.12 & 3 & 2338.27 & 2 & 2360.73 & 3 & 2383.83 & 2 & 2405.72 & 3 & 2433.44 & 2 \\
\hline 2309.79 & 2 & 2338.46 & 2 & 2360.88 & 2 & 2384.34 & 3 & 2407.23 & 2 & 2433.71 & 2 \\
\hline 2310.14 & $3 \mathrm{~h}$ & 2339.02 & 4 & 2361.85 & 2 & 2384.51 & 2 & $240 \% .34$ & 2 & 2434.20 & 2 \\
\hline 2309.98 & 3 & 2339.14 & 1 & 2362.11 & 2 & 2384.73 & 5 & 2407.59 & 4 & 2434.34 & 2 \\
\hline 2310.72 & 5 & 2339.51 & 1 & 2362.32 & 3 & 2385.26 & $2 \mathrm{lc}$ & 2408.00 & 3 & 2434.83 & 2 \\
\hline 2311.01 & 3 & 2340.01 & 3 & 2362.62 & 8 & 2385.73 & $2 \mathrm{lc}$ & 2408.37 & 3 & 2435.20 & 5 \\
\hline 2311.01 & $3 \mathrm{w}$ & 2340.23 & 4 & 2362.78 & 2 & 2386.50 & 3 & 2408.84 & 3 & 2435.68 & 2 \\
\hline 2311.81 & 8 & 2341.11 & 2 & 2363.05 & 2 & 2386.65 & 2 & 2409.27 & 3 & 2435.86 & 1 \\
\hline 2312.52 & 3 & 2341.12 & 2 & 2363.24 & 2 & 2386.91 & 3 & 2409.83 & 8 & 2436.09 & 4 \\
\hline 2313.17 & 3 & 2341.39 & 1 & 2363.98 & 2 & 2387.05 & 2 & 2409.99 & 2 & 2436.33 & 3 \\
\hline 2313.39 & 2 & 2343.03 & 2 & 2364.28 & 3 & 2387.14 & 2 & 2411.22 & 3 & 2436.81 & 3 \\
\hline 2313.54 & 1 & 2343.36 & $5 \mathrm{sh}$ & 2364.42 & 1 & 2387.63 & 4 & 2411.57 & 2 & 2439.19 & 3 \\
\hline 2313.71 & 1 & 2344.10 & 4 & 2364.55 & 2 & 2387.74 & 3 & 2412.13 & 2 & 2439.56 & 3 \\
\hline 2314.06 & 1 & 2344.34 & 2 & 2364.92 & 1 & 2388.39 & 2 & 2412.29 & 2 & 2439.74 & 1 \\
\hline 2314.24 & 3 & 2344.83 & 2 & 2365.00 & 1 & 2388.54 & 3 & 2412.55 & 2 & 2440.57 & 3 \\
\hline 2314.67 & 1 & 2345.02 & 3 & 2365.13 & 4 & 2388.86 & 3 & 2412.90 & $1 \mathrm{~d}$ & 2440.88 & 2 \\
\hline 2315.05 & 2 & 2345.34 & 4 & 2365.71 & 3 & 2389.39 & 2 & 2413.22 & 2 & 2441.96 & 8 \\
\hline 2315.38 & 5 & 2345.61 & 1 & 2365.94 & 3 & 2389.51 & 2 & 2413.76 & 2 & 2442.62 & 2 \\
\hline 2315.80 & 3 & 2346.12 & 2 & 2366.65 & 3 & 2389.68 & 3 & 2413.88 & 2 & 2442.89 & 1 \\
\hline 2316.44 & 2 & 2346.33 & 2 & 2366.93 & 8 & 2390.02 & 3 & 2414.75 & 2 & 2443.12 & 1 \\
\hline 2316.89 & 2 & 2346.54 & 8 & 2367.11 & 5 & 2390.37 & 2 & 2414.92 & 2 & 2443.60 & 2 \\
\hline 2317.29 & 3 & 2347.01 & 5 & 2368.56 & 1 & 2390.89 & 2 & 2415.07 & 2 & 24.43 .81 & 2 \\
\hline 2317.84 & 3 & 2347.30 & 6 & 2368.75 & 3 & 2391.04 & 4 & 2415.48 & 2 & 2444.63 & 2 \\
\hline 2318.38 & 3 & 2347.58 & 1 & 2368.98 & 3 & 2391.43 & 4 & 2415.75 & 2 & 2444.78 & 2 \\
\hline 2318.86 & 3 & 2347.98 & 3 & 2369.22 & 3 & 2391.60 & 2 & 24.16 .24 & 2 & 2444.95 & 2 \\
\hline 2319.11 & 5 & 2348.46 & 2 & 2369.61 & 3 & 2391.97 & 2 & 2416.81 & 8 & 2445.38 & 2 \\
\hline 2319.96 & 1 & 2348.67 & 2 & 2370.41 & 2 & 2392.50 & 4 & 2416.99 & 4 & 2445.48 & 4 \\
\hline 2320.08 & 2 & 2349.03 & 3 & 2370.86 & 3 & 2392.81 & 2 & 2417.07 & 5 & 2446.27 & 3 \\
\hline 2320.32 & 21 & 2349.37 & 3 & 2371.15 & 3 & 2393.15 & 3 & 2419.74 & $3 \mathrm{~d}$ & 2446.37 & 2 \\
\hline 2320.79 & 4 & 2349.72 & 8 & 2371.28 & 3 & 2393.26 & 4 & 2420.04 & 3 & 2446.53 & 3 \\
\hline 2321.18 & 6 & 2350.19 & 3 & 2372.15 & 8 & 2393.57 & 4 & 2420.41 & 2 & 2446.70 & 2 \\
\hline 2321.34 & 2 & 2350.35 & 3 & 2372.42 & 1 & 2393.71 & 3 & 2420.78 & 1 & 2446.93 & 2 \\
\hline 2321.78 & 1 & 2350.48 & 5 & 2372.83 & 2 & 2393.96 & 2 & 2421.05 & 8 & 2447.02 & 5 \\
\hline 2322.28 & 2 & 2351.18 & 4 & 2372.95 & 2 & 2394.02 & 2 & 2421.42 & 2 & 2447.09 & 2 \\
\hline 2322.50 & 2 & 2351.50 & 2 & 2373.19 & 3 & 2394.36 & 3 & 2421.88 & 3 & 2447.61 & 2 \\
\hline 2322.71 & 3 & 2351.75 & 51 & 2373.32 & 2 & 2394.82 & 2 & 2422.26 & 2 & 2448.45 & 1 \\
\hline 2323.70 & 3 & 2352.15 & 5 & 2373.42 & 2 & 2394.95 & 1 & 2422.38 & 2 & 2448.78 & 1 \\
\hline 2324.33 & 4 & 2352.56 & 3 & 2373.88 & 2 & 2395.20 & 3 & 2422.60 & 4 & 2449.70 & 3. \\
\hline 2324.50 & & 2353.00 & 1 & 2374.16 & 5 & 2395.35 & 3 & 2423.24 & 8 & 2449.83 & 2 \\
\hline 2324.81 & 3 & 2353.12 & 2 & 2374.43 & 2 & 2395.73 & 2 & 2423.84 & 3 & 2450.33 & 2 \\
\hline 2325.04 & 1 & 2353.24 & 2 & 2374.97 & 1 & 2396.26 & 4 & 2424.25 & 2 & 2450.48 & 3 \\
\hline 2325.16 & 1 & 2353.42 & 1 & 2375.07 & $5 \mathrm{~h}$ & 2396.84 & 3 & 2425.00 & 1 & 2450.60 & 2 \\
\hline 2325.40 & 3 & 2353.79 & 2 & 2375.50 & 2 & 2397.08 & 2 & 2425.29 & 1 & 2451.09 & 1 \\
\hline 2325.58 & $2 \mathrm{w}$ & 2354.24 & 3 & 2375.64 & 4 & 2397.28 & 2 & 2425.45 & 3 & 2451.35 & 1 \\
\hline 2325.85 & 2 & 2354.33 & 2 & 2376.00 & 3 & 2397.40 & 1 & 2425.75 & 1 & 2451.79 & 3 \\
\hline 2325.92 & 2 & 2354.59 & 2 & 2376.20 & 2 & 2398.02 & 3 & 2426.04 & 3 & 2452.00 & 3 \\
\hline 2326.07 & 4 & 2354.79 & 4 & 2376.66 & $4 \mathrm{~s}$ & 2398.21 & 4 & 2426.26 & 2 & 2452.12 & 3 \\
\hline 2326.86 & 3 & 2355.25 & 2 & 2377.17 & 4 & 2398.57 & 3 & 2426.44 & 1 & 2452.77 & 3 \\
\hline 2327.43 & 3 & 2355.26 & 2 & 2377.51 & 3 & 2398.98 & 2 & 2426.73 & 2 & 2453.21 & 3 \\
\hline 2327.97 & 2 & 2355.47 & 3 & 2378.08 & 1 & 2399.33 & 1 & 2427.46 & 3 & 2453.28 & 3 \\
\hline 2328.13 & 3 & 2355.47 & 3 & 2378.47 & 8 & 2399.42 & 2 & 2427.72 & 1 & 2453.52 & 3 \\
\hline 2328.59 & 3 & 2355.90 & 2 & 2378.90 & $2 \mathrm{~d}$ & 2400.51 & 2 & 2428.27 & 1 & 2453.82 & 2. \\
\hline 2328.76 & 2 & 2356.04 & 2 & 2379.34 & 3 & 2401.36 & 3 & 2428.46 & $2 \mathrm{~h}$ & 2454.11 & 1 \\
\hline 2329.02 & 3 & 2356.20 & 3 & 2379.58 & 2 & 2401.54 & 3 & 2428.81 & 2 & 2454.40 & 3. \\
\hline 2329.87 & $3 \mathrm{w}$ & 2356.54 & 3 & 2379.88 & 2 & 2401.71 & 2 & 2428.98 & 2 & 2454.60 & 2 \\
\hline 2330.34 & 1 & 2356.85 & 8 & 2380.11 & 3 & 2401.94 & 2 & 2429.11 & 1 & 2454.87 & 2 \\
\hline 2330.79 & 4 & 2357.13 & 2 & 2380.50 & 2 & 2402.52 & 2 & 2429.72 & 2 & 2455.18 & 3. \\
\hline 2332.01 & 5 & 2357.58 & 1 & 2380.57 & 2 & 2402.64 & 1 & 2429.84 & 3 & 2455.26 & 2 \\
\hline 2332.40 & 3 & 2357.97 & 2 & 2380.89 & 2 & 2403.89 & 3 & 2430.40 & 2 & 2455.50 & 2 \\
\hline 2332.52 & 4 & 2358.24 & 1 & 2381.07 & $2 \mathrm{~d}$ & 2404.14 & 5 & 2430.57 & 3 & 2455.98 & 1 \\
\hline 2333.04 & 1 & 2358.69 & 2 & 2381.44 & 2 & 2404.30 & 1 & 2430.76 & 2 & 2456.36 & 2 \\
\hline 2333.36 & 2 & 2358.77 & 1 & 2381.72 & 2 & 2404.50 & 1 & 2431.35 & 5 & 2456.85 & 2 \\
\hline
\end{tabular}


TABLE 1. - W avelengths and intensities of absorption lines of $\mathrm{Pr}-$ Continued

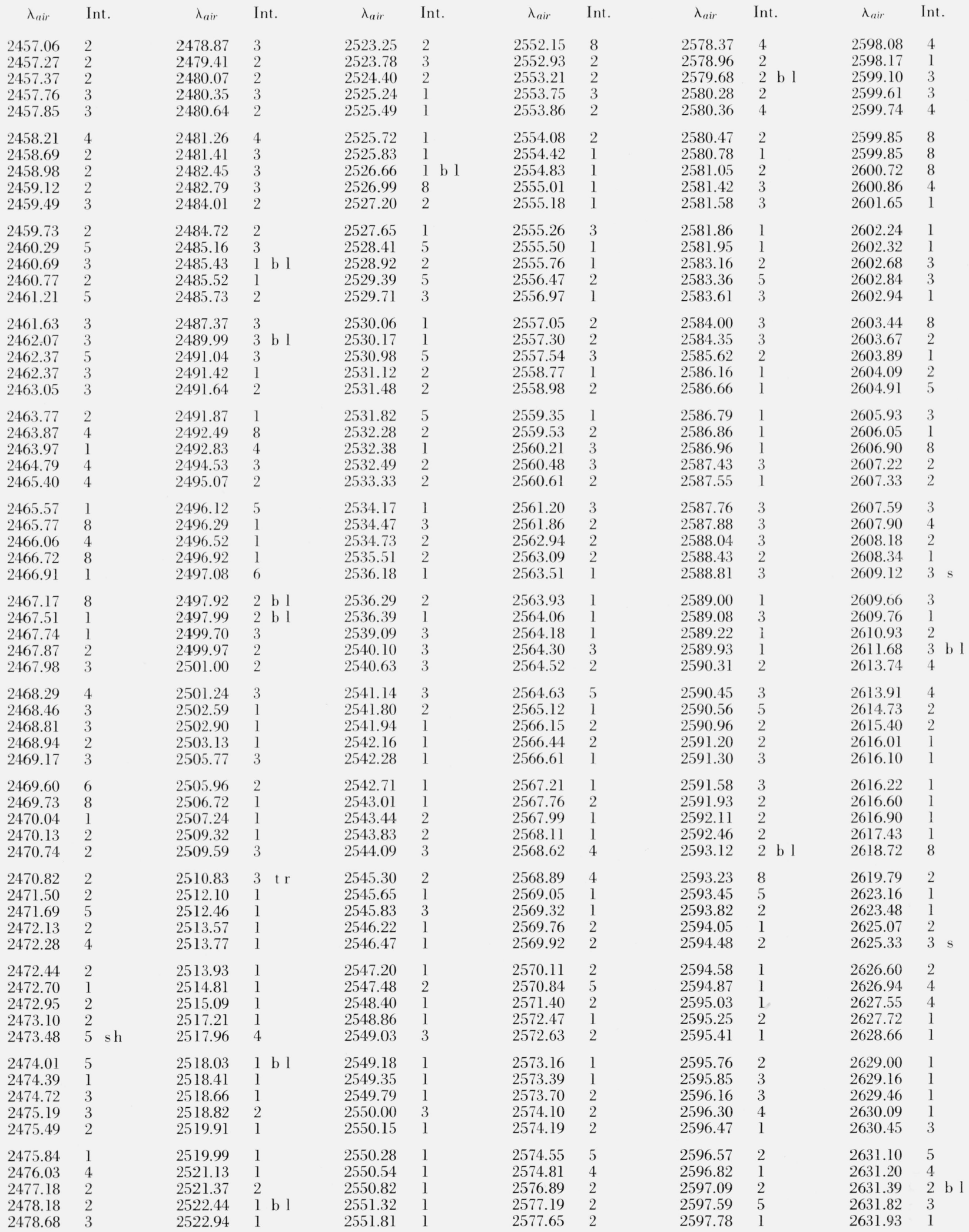


TABLE 1. - Wavelengths and intensities of absorption lines of $\mathrm{Pr}-$ Continued

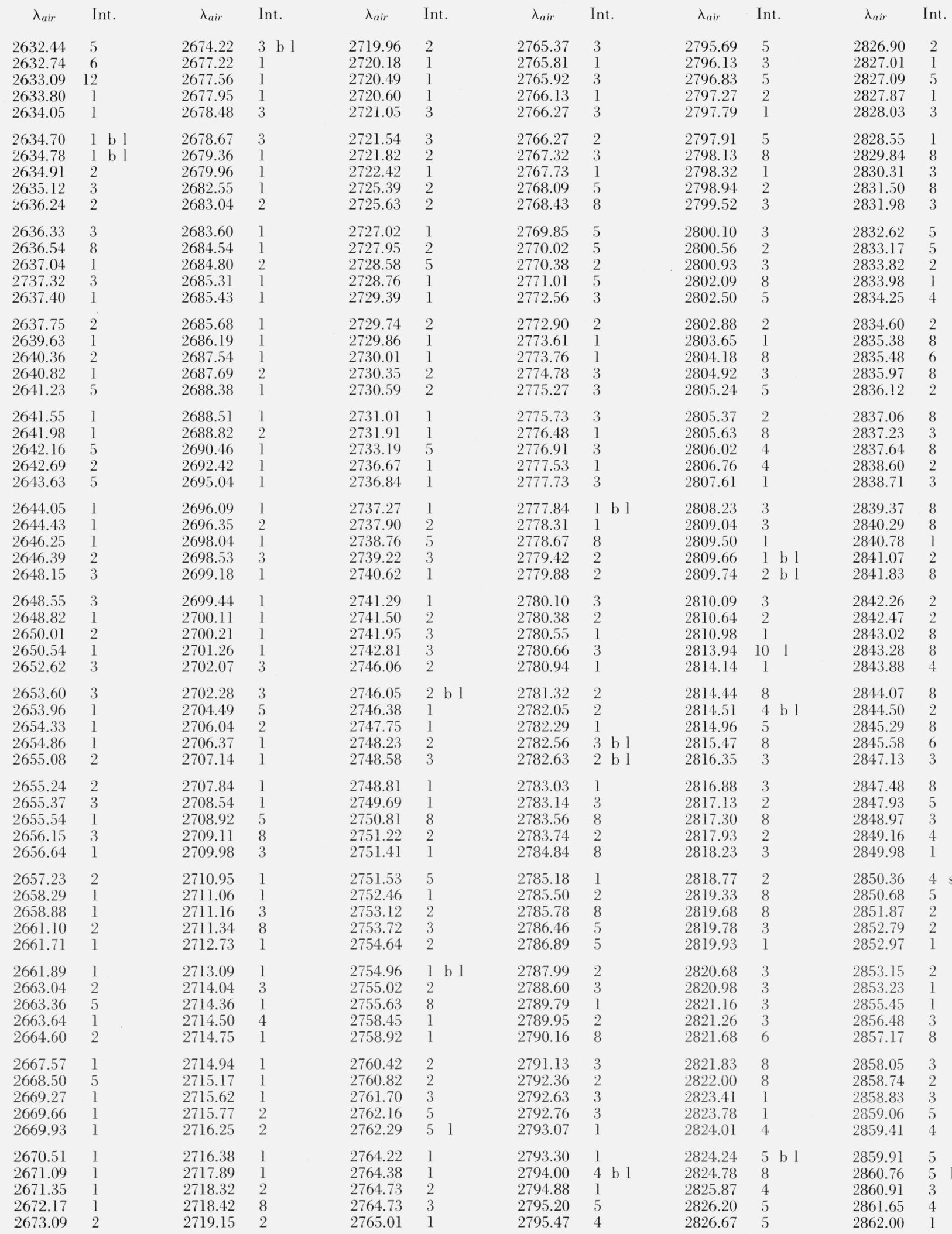


TABLE 1. - W avelengths and intensities of absorption lines of $\mathrm{Pr}-$ Continued

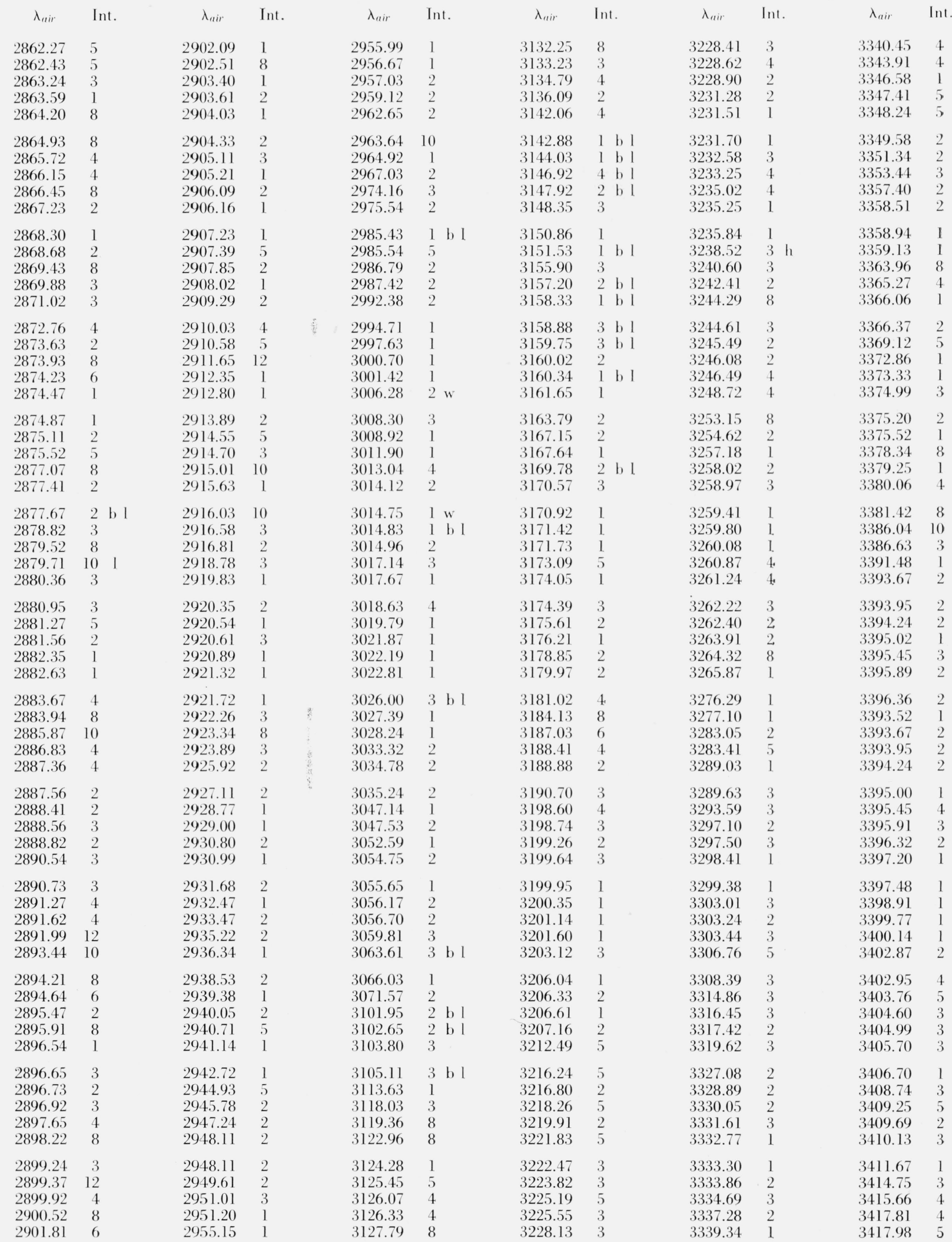


TABLE 1. - W avelengths and intensities of absorption lines of $\mathrm{Pr}-\mathrm{Continued}$

\begin{tabular}{|c|c|c|c|c|c|c|c|c|c|c|}
\hline$\lambda_{\text {air }}$ & Int. & $\lambda_{\text {air }}$ & Int. & $\lambda_{\text {air }}$ & Int. & $\lambda_{\text {air }}$ & Int. & $\lambda_{\text {air }}$ & Int. & $\lambda_{\text {air }}$ \\
\hline 3418.66 & 1 & 3516.33 & 1 & 3644.70 & 1 & 3738.94 & 2 & 3832.31 & 3 & 3961.70 \\
\hline 3420.83 & 1 & 3517.17 & 1 & 3649.08 & 2 & 3739.59 & 1 & 3833.07 & 2 & 3961.85 \\
\hline 3421.94 & 1 & 3518.49 & 10 & 3650.73 & 4 & 3739.80 & 1 & 3833.23 & 2 & 3962.85 \\
\hline 3422.43 & 1 & 3519.65 & 3 & 3651.46 & l & 3744.80 & 5 & 3834.35 & 3 & 3963.24 \\
\hline 3423.26 & 2 & 3521.32 & 2 & 3651.98 & 1 & 3748.98 & 3 & 3834.69 & 4 & 3964.90 \\
\hline 3425.20 & 3 & 3522.97 & 3 & 3653.37 & 1 & 3750.38 & 5 & 3836.10 & 5 & 3965.26 \\
\hline 3426.08 & 2 & 3523.19 & 3 & 3654.13 & 1 & 3756.13 & 2 & 3836.30 & 2 & 3966.28 \\
\hline 3426.72 & 1 & 3527.86 & 1 & 3654.63 & 5 & 3757.06 & 1 & 3838.77 & 2 & 3966.55 \\
\hline 3432.04 & 10 & 3529.61 & 1 & 3657.09 & 3 & 3758.35 & 1 & 3844.10 & 2 & 3966.88 \\
\hline 3432.63 & 2 & 3529.84 & 2 & 3658.04 & 2 & 3758.84 & 1 & 3848.10 & 3 & 3969.30 \\
\hline 3434.47 & 4 & 3530.66 & 1 & 3659.20 & 1 & 3760.22 & 4 & 3850.38 & 4 & 3971.63 \\
\hline 3436.89 & 1 & 3532.29 & 1 & 3661.48 & 3 & 3760.69 & 1 & 3858.02 & 4 & 3972.70 \\
\hline 3437.60 & 4 & 3532.82 & 8 & 3662.47 & 3 & 3760.96 & 3 & 3859.11 & 2 & 3973.71 \\
\hline 3438.85 & 2 & 3542.08 & 2 & 3664.38 & 1 & 3761.37 & 1 & 3861.78 & 1 & 3974.32 \\
\hline 3440.06 & 1 & 3543.74 & 5 & 3665.07 & 2 & 3763.11 & l & 3864.10 & 1 & 3974.67 \\
\hline 3440.59 & 1 & 3544.59 & 1 & 3665.46 & 1 & 3763.97 & 1 & 3866.59 & 4 & 3976.94 \\
\hline 3440.97 & 1 & 3549.26 & 1 & 3666.38 & 2 & 3764.90 & 8 & 3870.72 & 1 & 3977.32 \\
\hline 3441.57 & 2 & 3550.65 & $3 \mathrm{~h}$ & 3668.47 & 5 & 3766.02 & 1 & 3872.64 & 2 & 3977.69 \\
\hline 3442.40 & 2 & 3551.41 & 3 & 3668.88 & 1 & 3766.75 & 5 & 3874.83 & 1 & 3978.17 \\
\hline 3443.24 & 2 & 3551.65 & 2 & 3671.11 & 4 & 3768.42 & 5 & 3877.29 & $4 \mathrm{~h}$ & 3978.60 \\
\hline 3444.30 & 4 & 3555.26 & 2 & 3675.50 & 3 & 3768.95 & 3 & 3878.21 & 4 & 3979.66 \\
\hline 3445.83 & 1 & 3558.81 & 2 & 3676.08 & 4 & 3769.93 & l & 3878.80 & 2 & 3979.88 \\
\hline 3447.83 & 5 & 3563.50 & 8 & 3677.59 & 3 & 3770.80 & 2 & 3881.69 & 1 & 3980.23 \\
\hline 3450.10 & 5 & 3564.13 & 5 & 3678.30 & 5 & 3773.47 & 5 & 3883.30 & 5 & 3980.48 \\
\hline 3450.66 & 2 & 3564.76 & 1 & 3679.91 & $2 \mathrm{~h}$ & 3776.07 & 6 & 3883.98 & 3 & 3980.87 \\
\hline 3453.80 & 5 & 3572.30 & $9 \mathrm{~s}$ & 3681.69 & 5 & 3779.29 & 4 & 3884.28 & 1 & 3981.39 \\
\hline 3454.86 & 1 & 3573.09 & 1 & 3683.52 & 2 & 3779.73 & 1 & 3886.30 & 1 & 3981.68 \\
\hline 3458.06 & 2 & 3575.62 & 2 & 3685.76 & 3 & 3780.29 & 2 & 3892.40 & 2 & 3982.07 \\
\hline 3459.44 & 1 & 3577.16 & 1 & 3687.67 & 5 & 3780.94 & 2 & 3895.63 & 3 & 3982.46 \\
\hline 3459.86 & 2 & 3578.68 & 5 & 3687.86 & 1 & 3782.82 & 3 & 3898.41 & 4 & 3982.70 \\
\hline 3461.20 & 3 & 3582.97 & 3 & 3693.61 & $8 \mathrm{~s}$ & 3783.81 & 1 & 3899.36 & 3 & 3983.36 \\
\hline 3466.24 & 3 & 3586.64 & 1 & 3695.46 & 4 & 3785.07 & 3 & 3900.67 & 2 & 3983.52 \\
\hline 3467.02 & 3 & 3590.84 & 2 & 3698.74 & 3 & 3786.11 & 1 & 3901.29 & 1 & 3983.84 \\
\hline 3468.55 & 1 & 3591.21 & 3 & 3700.24 & 3 & 3787.90 & 4 & 3901.81 & 1 & 3984.42 \\
\hline 3468.66 & 2 & 3591.90 & 2 & 3701.59 & 2 & 3788.19 & l & 3906.82 & 1 & 3985.04 \\
\hline 3469.05 & 5 & 3593.50 & 5 & 3702.89 & 1 & 3789.73 & 5 & 3909.22 & 1 & 3985.65 \\
\hline 3470.06 & 1 & 3599.03 & 1 & 3703.33 & 3 & 3791.21 & 1 & 3910.57 & 5 & 3986.10 \\
\hline 3470.33 & 3 & 3603.65 & 2 & 3705.14 & 1 & 3791.42 & 1 & 3912.29 & 1 & 3986.75 \\
\hline 3471.68 & 1 & 3604.48 & 1 & 3706.05 & $3 \mathrm{~h}$ & 3792.52 & 4 & 3913.03 & l & 3987.04 \\
\hline 3474.46 & 4 & 3605.31 & 4 & 3707.63 & 2 & 3792.95 & 4 & 3913.53 & 2 & 3987.18 \\
\hline 3475.51 & 5 & 3605.79 & 3 & 3708.37 & 2 & 3793.61 & 1 & 3916.62 & 1 & 3987.61 \\
\hline 3478.36 & 3 & 3606.20 & 3 & 3708.66 & 2 & 3794.17 & 3 & 3921.08 & 2 & 3990.07 \\
\hline 3479.25 & 3 & 3609.61 & 1 & 3711.17 & 4 & 3794.77 & 3 & 3922.86 & 2 & 3990.59 \\
\hline 3479.84 & 2 & 3612.33 & 1 & 3713.44 & 1 & 3795.30 & 2 & 3923.62 & 3 & 3991.47 \\
\hline 3482.09 & 3 & 3616.23 & 2 & 3715.62 & 4 & 3796.16 & 2 & 3924.49 & 8 & 3992.31 \\
\hline 3482.61 & 2 & 3617.39 & 3 & 3716.47 & 1 & 3797.34 & 2 & 3934.09 & 4 & 3992.99 \\
\hline 3483.31 & 3 & 3617.62 & $8 \mathrm{~s}$ & 3719.92 & 3 & 3797.69 & 2 & 3934.69 & 1 & 3994.33 \\
\hline 3485.75 & 2 & 3620.78 & 1 & 3721.68 & 4 & 3800.43 & 2 & 3935.02 & 5 & 3995.95 \\
\hline 3487.55 & 1 & 3621.24 & 1 & 3723.78 & 1 & 3801.49 & 3 & 3935.90 & 1 & 3997.78 \\
\hline 3489.31 & 1 & 3622.20 & 5 & 3724.15 & 5 & 3803.18 & 5 & 3936.21 & 1 & 3998.09 \\
\hline 3489.62 & 1 & 3625.58 & 1 & 3724.37 & 5 & 3806.26 & 2 & 3937.20 & 3 & 3999.38 \\
\hline 3490.99 & 2 & 3626.41 & 1 & 3725.52 & 1 & 3807.31 & 2 & 3937.37 & 3 & 4000.15 \\
\hline 3491.36 & l b l & 3627.42 & 2 & 3726.45 & 1 & 3807.61 & 1 & 3938.11 & 1 & 4000.81 \\
\hline 3491.51 & 2 b l & 3629.25 & 5 & 3728.78 & 1 & 3811.17 & 4 & 3941.26 & 1 & 4001.07 \\
\hline 3494.83 & 5 & 3629.96 & 1 & 3729.95 & 2 & 3811.70 & 3 & 3941.41 & 1 & 4001.98 \\
\hline 3495.83 & 1 & 3631.99 & 1 & 3729.92 & 2 & 3812.47 & 4 & 3942.44 & 5 & 4002.68 \\
\hline 3500.32 & $10 \mathrm{~s}$ & 3632.45 & 1 & 3730.71 & 1 & 3814.95 & 2 & 3943.90 & 6 & 4005.73 \\
\hline 3503.75 & 3 & 3633.16 & 5 & 3732.49 & 5 & 3817.61 & $3 \mathrm{~s}$ & 3945.41 & 5 & 4007.27 \\
\hline 3506.99 & 3 & 3634.39 & 1 & 3733.74 & 1 & 3820.16 & 5 & 3946.22 & 8 & 4008.33 \\
\hline 3509.57 & 2 & 3634.91 & 1 & 3734.02 & 4 & 3822.63 & 1 & 3948.59 & 3 & 4009.37 \\
\hline 3510.07 & 2 & 3642.23 & 1 & 3734.77 & 1 & 3822.79 & 2 & 3951.99 & 2 & 4010.17 \\
\hline 3510.21 & 1 & 3642.49 & 1 & 3736.05 & 3 & 3823.32 & 3 & 3953.67 & 2 & 4010.87 \\
\hline 3511.18 & 1 & 3643.06 & 3 & 3736.57 & 2 & 3824.10 & 4 & 3954.72 & 5 & 4011.18 \\
\hline 3512.04 & 1 & 3643.64 & 2 & 3737.14 & 1 & 3824.57 & 2 & 3955.23 & 5 & 4011.50 \\
\hline 3512.99 & 1 & 3644.00 & 2 & 3738.67 & 1 & 3830.94 & 2 & 3956.35 & 2 & 4013.55 \\
\hline
\end{tabular}


TABLE 1. - Wavelengths and intensities of absorption lines of $\mathrm{Pr}-$ Continued

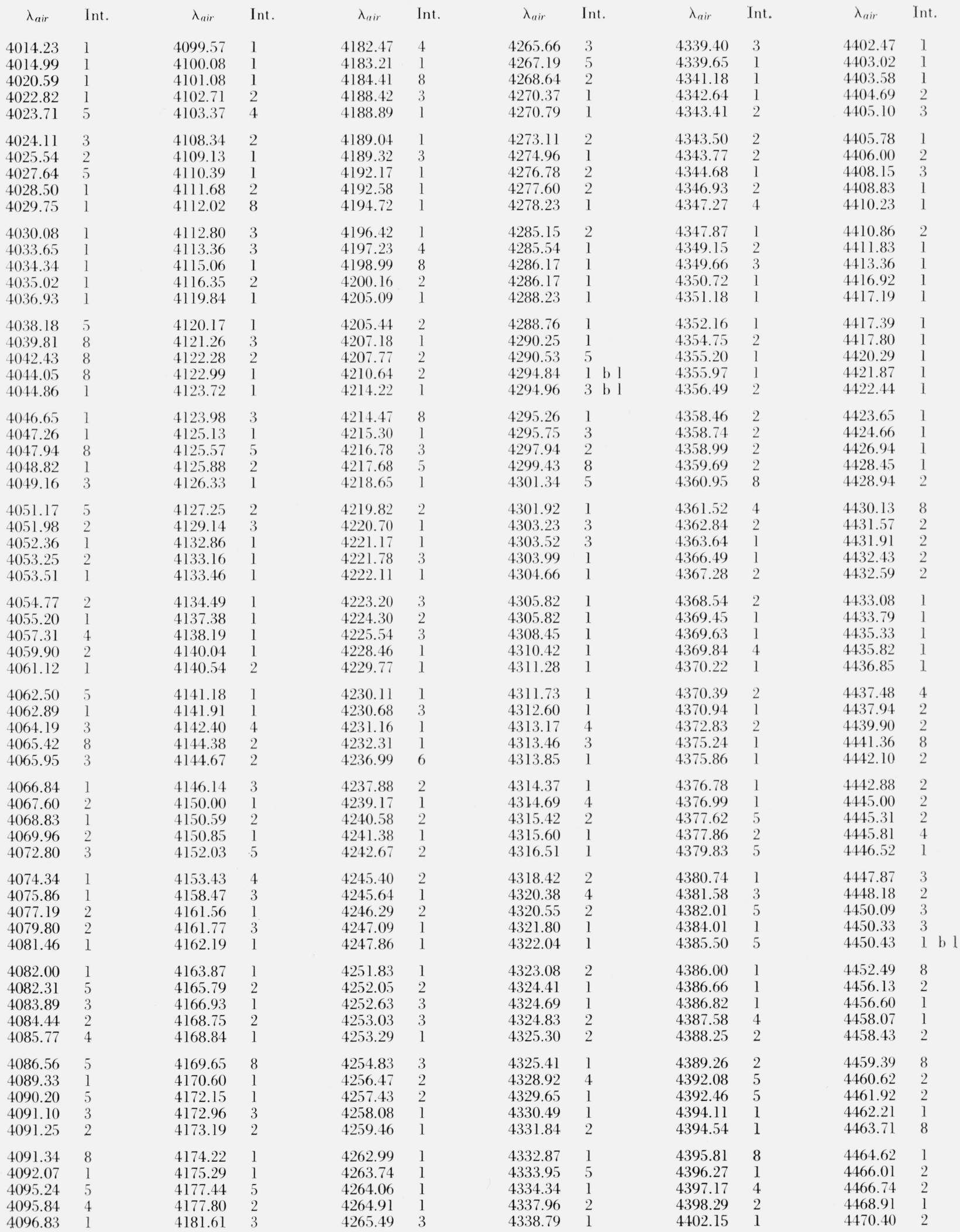


TABLE 1. - W avelengths and intensities of absorption lines of $\mathrm{Pr}$-Continued

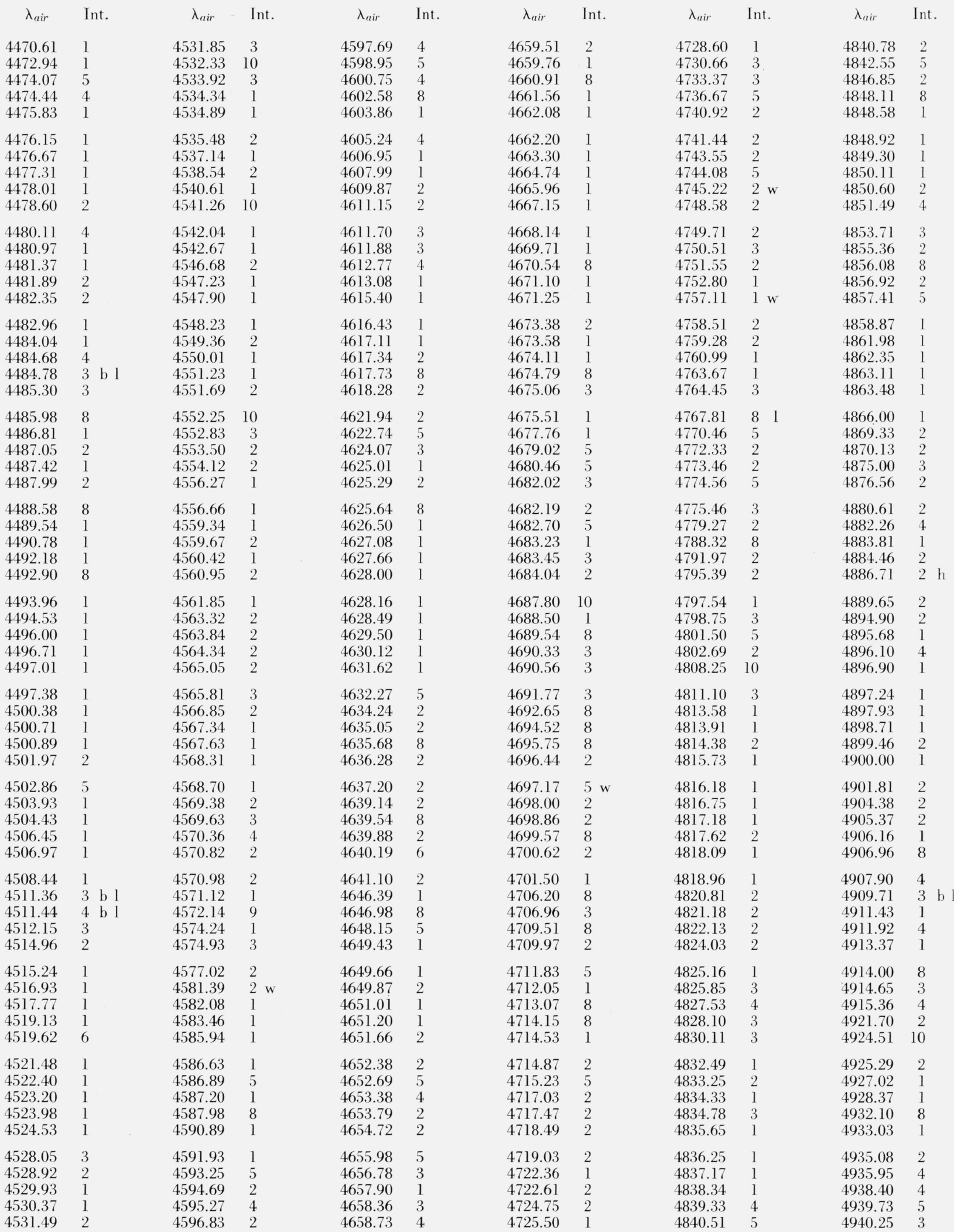


TABLE 1. - W avelengths and intensities of absorption lines of $\mathrm{Pr}-$ Continued

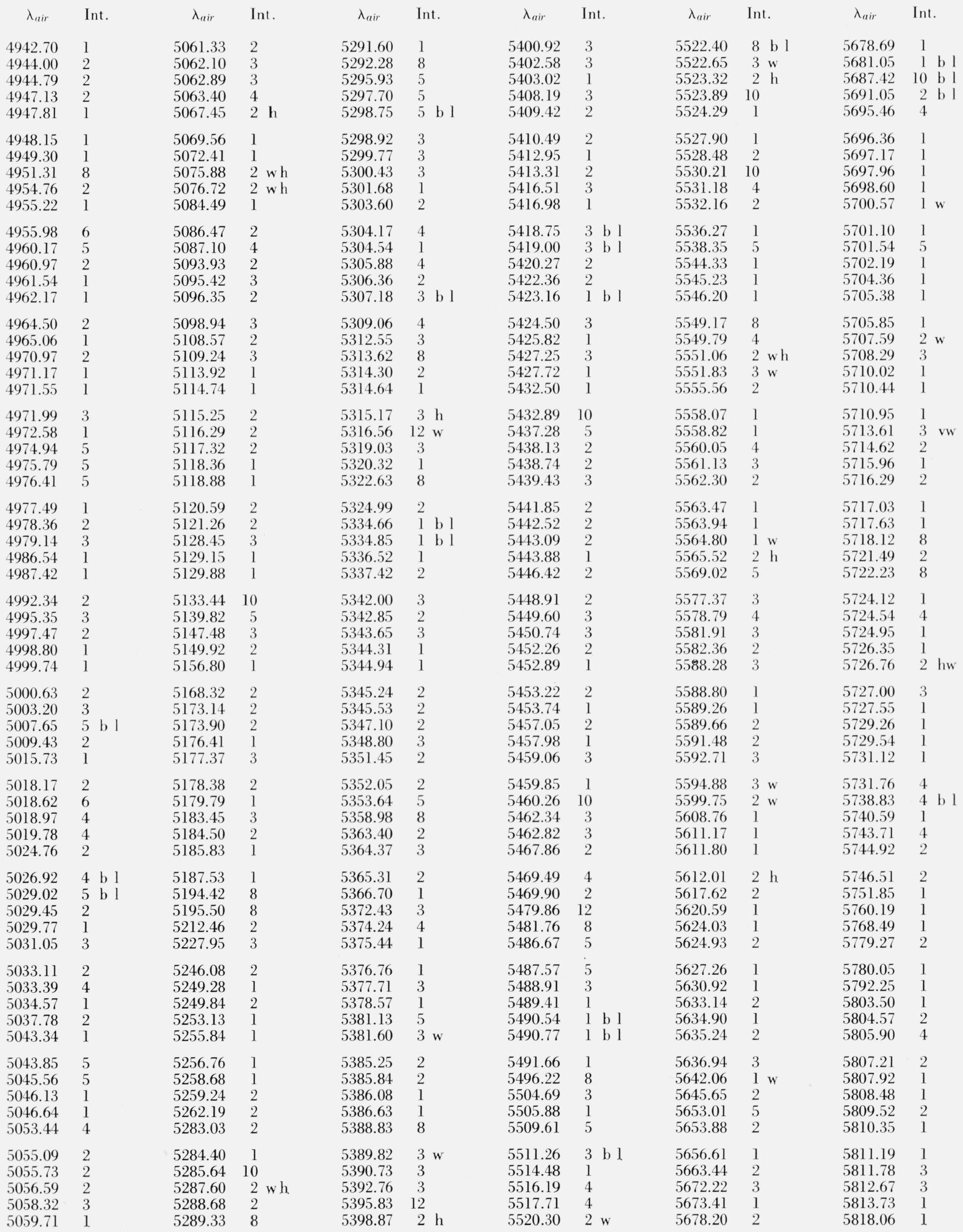


TABLE 1. - Wavelengths and intensities of absorption lines of $\mathrm{Pr}-$ Continued

\begin{tabular}{|c|c|c|c|c|c|c|c|c|c|c|c|}
\hline$\lambda_{\text {air }}$ & Int. & $\lambda_{\text {air }}$ & Int. & $\lambda_{\text {air }}$ & Int. & $\lambda_{\text {air }}$ & Int. & $\lambda_{\text {air }}$ & Int. & $\lambda_{\text {air }}$ & Int. \\
\hline 5818.93 & 1 & 5820.79 & $6 \mathrm{~s}$ & 5823.23 & 1 & 5828.93 & 1 & 5831.81 & l & 5834.51 & 2 \\
\hline 5819.95 & 1 & 5821.33 & $4 \mathrm{w}$ & 5824.14 & 2 & 5829.32 & 1 & 5832.25 & 2 & 5835.12 & 8 \\
\hline 5820.10 & l & 5822.43 & $2 w$ & 5824.65 & 3 & 5830.05 & I & 5832.98 & 1 & 5837.71 & 5 \\
\hline 5820.34 & $2 \mathrm{w}$ & 5822.97 & 1 & 5825.14 & 1 & 5831.45 & 3 & 5833.73 & 2 & 5839.03 & 1 \\
\hline
\end{tabular}

(Paper 69A1-329) 


\title{
Publications of the National Bureau of Standards*
}

\author{
Selected Abstracts
}

Hydrodynamic fluctuations and Stokes' law friction, R. Zwanzig, J. Res. 68B (Math. and Math. Phys.), No. 4, 143-145 (Oct.-Dec. 1964).

The frictional force on a Brownian motion particle can be expressed by means of the time-correlation of the fluctuating force on the particle. We show that this method, applied to a spherical particle in a viscous incompressible fluid, leads to Stokes' Law. The calculation is based on the theory of hydrodynamic fluctuations due to Landau and Lifshitz, and on a hydrodynamic theorem due to Faxen.

Tables of electron radial functions and tangents of phase shifts for light nuclei $(\mathbf{Z}-\mathbf{1}$ through 10$)$, C. P. Bhalla, NBS Mono. 81, (Aug. 6, 1964), \$3.25.

To facilitate the theoretical analyses of beta-decay experiments in light nuclei electronic radial wave functions, evaluated at the nuclear radius, and tangents of phase-shifts are tabulated for total angular momentum equal to $1 / 2$ and $3 / 2$. Separate tables for electrons and positrons are given for ten values of $Z$, starting from $Z$ equal to one, in steps of unity and for beta momentum values from $0.1 \mathrm{mc}$ to $42.0 \mathrm{mc}$ in steps of $0.1 \mathrm{mc}$. The nucleus is represented as a sphere with uniform charge distribution. The nuclear radius, $p$, is taken to be $1.2 A^{1 / 3} 10^{-13} \mathrm{~cm}$ in the major body of these tables. However, additional tables for $Z=6$ and $Z=7$ are given for $p=1.1 A^{1 / 3} 10^{-13} \mathrm{~cm}$ and $p=1.3 A^{1 / 3} 10^{-13} \mathrm{~cm}$.

Project FIST. Fault isolation by semi-automatic techniques, G. Shapiro, O. B. Laug, G. J. Rogers, and P. M. Fulcomer, Jr., NBS Mono. 83, (Sept. 17, 1964), 55 Cents.

The method of Fault Isolation by Semi-automatic Techniques developed at the National Bureau of Srandards, to which the acronym FIST has been applied, creates a new field of metrology which permits the measurement of the dynamic performance of electronic circuits by unskilled personnel under field operating conditions. It is a diagnostic tool for rapidly isolating faults in modularized, non-computer type electronic equipment without removing the modules from the prime equipment.

The system consists of test points and associated circuitry which are built into the prime equipment, and a small, handcarried, general-purpose test instrument. The test points are located on an easily accessible test panel and are arranged in an order which permits rapid checking of the modules in a logical sequence.

Fault isolation is accomplished by testing the dynamic performance of each module with a test instrument which is basically a device for comparing the peak-to-peak amplitudes of two periodic voltage waveforms. Since many circuit properties other than voltage must be measured, transformation networks are provided to convert the characteristic being measured to a periodic voltage which is within the range of the test instrument.

The tests are usually made while the module under test is performing its normal function with the normal inputs to the module providing the stimuli for the tests when this is not possible, a stimulus generator is used to furnish the necessary signal or signals.

These techniques have been reduced to practice. This report describes the hardware required and discusses practical ways in which the necessary circuitry can be built into the prime equipment. The simplicity of the programming and the speed with which a complex piece of electronic equipment can be checked are demonstrated. Finally, a prototype test instrument capable of simultaneously testing four characteristics of the module or of its stimuli is described in detail.
United States standard for the colors of signal lights, F. C. Breckenridge, NBS Handb. 95 (Aug. 21, 1964), 25 cents.

The standard provides in part I basic chromaticity definitions defining the chromaticities that are considered safe for use as representing the named colors. These are the basis for the selection of the national standard filters and for the tolerances given in part II for duplicating them. The procurement requirements of parts III and IV are based primarily on sets of these filters in combination with prescribed sources although provision is also made for procurement under the basic chromaticity definitions in cases in which it is impracticable to base the procurement on filters. Part V provides guidance in selecting signal colors for new uses, and part VI provides methods for special laboratory tests and serves as a technical interpretation of the practical tests prescribed in parts III and IV.

Studies of photodissociation of molecular ions, G. H. Dunn, Book, Atomic Collision Processes, pp. 99\%-1005 (North-Holland Publ. Co., Amsterdam, The Netherlands, 1964).

Preliminary results are reported on the measurement of the photodissociation cross section of $\mathrm{H}_{2}{ }^{+}$. Measurements have been made at a number of wavelengths between $3000 \AA$ and $9000 \mathrm{~A}$, and a comparison is made with available theory. Disagreement of the measurements with theory suggest that improvement of the theory is justified for detailed comparisons with experiment.

A linear decrease with ion source pressure of the photodissociation cross section at $5500 \AA$ is observed. This dependence yields a lower limit of $10^{-15} \mathrm{~cm}^{2}$ on the collision cross section for depopulating vibrational states of $\mathrm{H}_{2}{ }^{+}$participating in photodissociation at $5500 \AA$.

White light was also used to observe photodissociation of $\mathrm{H}_{2}{ }^{+}$ and $\mathrm{N}_{2}{ }^{+}$, and an average cross section was calculated from the data and the spectral distribution of the lamp used.

An effort to observe photodissociation of $\mathrm{H}_{3}{ }^{+}$yielded no results except to place an upper limit of $10^{-20} \mathrm{~cm}^{2}$ on the average cross section.

Mechanical and dielectric relaxation of crystalline polymers in relation to degree of crystallinity and morphology, E. Passaglia, Soc. Plastic Engrs., pp. 169-177 (July 1964).

Mechanical and dielectric relaxation as related to the morphology of crystalline polymers is reviewed. The behavior with temperature of the imaginary part of the complex dielectric constant and the mechanical loss factor, tan $\delta$, at constant frequency is discussed in detail for two typical crystalline polymers: poly(chlorotrifluoroethylene) and polypropylene. Three relaxations are typically observed: a low temperature relaxation occurring at temperatures below the dilotometric glass transition temperature; a glass temperature relaxation occurring near the glass transition temperature, and a high temperature relaxation occurring between the glass temperature and the melting point. The activation parameters are given for these relaxations, and the influence of morphology on them is discussed along with possible molecular interpretations.

Unitary symmetry in photoproduction and other electromagnetic interactions, C. A. Levinson, H. J. Lipkin, and S. Meshkov, Physics Letters $\boldsymbol{\gamma}$, No. 1, 81-84 (Oct. 15, 1963).

$\mathrm{U}$-spin is rigorously conserved to all orders in the electromagnetic interaction and in the strong interactions which are 
invariant under $\mathrm{SU}_{3}$. Predictions which follow from $U$-spin conservation are given for 1) photoproduction, 2) meson photoproduction, 3) electromagnetic decays of baryon resonances, 4) static electromagnetic properties for the baryon octet, $5)$ photoproduction of two mesons, and 6) photoproduction of $\mathrm{Z}^{-}$.

Initial preparation and metastable transitions in mass spectra, H. M. Rosenstock, V. H. Dibeler, and F. N. Harllee, J. Chem. Phys. 40, No. 2, 591-594 (Jan. 15, 1964).

Variation of initial preparation to search for non-equilibrium kinetic effects (Frey) is discussed in connection with the kinetics of unimolecular ionic decomposition processes occurring in the mass spectrometer. A particular example, dependence of the rates of competing metastable transitions of hexyl ions on mode of preparation is studied in detail. The hexyl ions were prepared by electron impact ionization and decomposition of a variety of normal alkanes, $n$-hexvl bromide and di-n-hexyl ether. At low electron energies (30 ev) the ratio of the competing metastable transitions is constant within experimental error. This supports the applicability of the quasi-equilibrium theory of mass spectra to such processes. At higher electron energies there is a slight dependence of the ratio on parent ion mass.

Inelastic electron scattering from rare gases, determination of oscillator strengths in the continuum, C. E. Kuyatt and J. A. Simpson, Proc. Third Intern. Conf. Physics of Electronic and Atomic Collisions, London, England, 1963, pp. 191-200 (North Holland Publ. Co., Amsterdam, The Netherlands, 1964). The inelastic scattering of $500-1000 \mathrm{eV}$ electrons from the rare gases has been measured for small angle collisions and energy losses to $10 \mathrm{C} \mathrm{eV}$. Approximate relative oscillator strengths for continuum excitations of helium and neon have been derived from the forward scattering intensities. The results in helium are in good agreement with the latest uv measurements and with calculations. In the case of neon, previous experiments and calculations differ considerably. The present results agree well with the most recent uv measurements, except that the electron measurements do not show a sharp L ionization edge. This difference can probably be attributed to the effect of preionization lines with a resonance shape which have recently been observed.

The characterization of large single crystals by high-voltage X-ray Laue photographs, H. S. Peiser and E. P. Levine, (Proc. 11th Ann. Conf. Applications of X-ray Analysis, Aug. 1962), Book, Advances in X-ray Analysis 6, 158-163 (Plenum Press Inc., New York, N.Y., 1963).

Large single crystals can be examined by conventional X-ray diffraction procedures only at their surface or by destructive sectioning. With the limitations inherent in polychromatic X-ray photography, high-voltage Laue pictures are shown to give some information on the internal quality of large crystals. Asterism in conventional Laue photographs is contrasted with streaks due to geometric effects in Laue patterns of large crystals. Detail within the streaks reveals sub-grain structure. A primary extinction effect can be used as striking proof of good crystals being capable of scattering coherently over large distances.

The calculations of autoionization probabilities, J. W. Cooper, Proc. Third Intern. Conf. Physics of Electronic and Atomic Collisions, London, England, 1963, pp. 595-599 (North Holland Publ. Co., Amsterdam, The Netherlands, 1964). Calculations have been carried out for the autoionization probabilities and level widths of the doubly excited states $(2 s n p)^{1,3} P$ and $\left(n s^{2} p\right)^{1,3} P^{n=2}, 3,4$ in He. Although the model used for the calculations was crude, the level widths computed agree order of magnitude-wise with recent experimental observations. The probable effect of the strong coupling between levels of the above series for $n>2$ and of additional configuration mixing is discussed. The calculations point up the fact that the important region for the autoionization process corresponds to small radial distances from the nucleus. It was also found that the results were relatively insensitive to the exact form of the wave functions and for the calculations.
The basis of the functional assumption in the theory of the Boltzmann equation, M. S. Green and R. A. Piccirelli, Phys. Rev. 132, No. 3, 1388 (Nov. 1963).

The long-time behavior of the $n$-particle probability densities for a large, dilute system of point particles interacting with short-range forces is studied. The main result is an exact series for the $n$-particle density which consists of two parts. The first part is a time-independent functional of the singlet density which is expressed as a funtional power series and which is a direct analog of the equilibrium density series. The second part is also a functional power series in the singlet density but the coefficients depend on time and on the initial correlations. The coefficients of both series are given explicitly in terms of operators which are determined by the dynamics of isolated groups of particles. It is demonstrated that these operators vanish for phase points corresponding to motions during which there are two or more groups of particles which either are statistically and dynamically independent or are such that each of them is dynamically connected to the rest by no more than one particle. It is argued that all the terms of the exact series are finite and that the terms of second part (the error) decrease with increasing time so that the first part is the asymptotic form proposed by Bogoliubov. The relevance of the results for the Boltzmann equation is indicated.

Energy dependence for the photodetachment of $\mathrm{I}^{-}$near threshold, B. Steiner, M. L. Seman, and L. M. Branscomb, Proc. Third Intern. Conf. Physics of Electronic and Atomic Collisions, London, England, 1963, pp. 537-542 (North Holland Publ. Co., Amsterdam, The Netherlands, 1964).

The photodetachment of atomic iodine negative ions has been observed in a crossed beam experiment with much higher spectral resolution than previously used in this laboratory. The iodine negative ions were formed in a discharge through an ammonia-iodine vapor mixture and mass analyzed in the apparatus used in previous experiments. The photon beam originated in a high pressure xenon lamp and was resolved in an F/1.5 monochromator. The threshold region near 4040 $\AA$ has been scanned with a photon beam half width of $18 \AA$, and the region down to $3000 \AA$ with a half width of $33 \AA$. Transitions ascribed to ${ }^{1} \mathrm{~S}_{0} \rightarrow{ }^{2} \mathrm{P}_{3 / 2}^{0}$ and ${ }^{1} \mathrm{~S}_{0} \rightarrow{ }^{2} \mathrm{P}_{1 / 2}^{0}$ were observed. The experimental slit function has been unfolded from the first threshold region to reveal the "true" threshold behavior. The derived radiative attachment cross section in region of the threshold will be presented.

Nuclear magnetic resonances of ${ }^{69} \mathrm{Ga}$ and ${ }^{71} \mathrm{Ga}$ in galliumsubstituted yttrium iron garnet, R. L. Streever and G. A. Uriano, Phys. Rev. Letters 12, No. 22, J516 1-3-J516 3-3 (June 1, 1964).

We have recently observed the nuclear magnetic resonance of ${ }^{69} \mathrm{Ga}$ and ${ }^{71} \mathrm{Ga}$ in the mixed garnet system $3 \mathrm{Y}_{2} \mathrm{O}_{3} \cdot(5-\mathrm{x})$ $\mathrm{Fe}_{2} \mathrm{O}_{3} \cdot \mathrm{xGa}_{2} \mathrm{O}_{3}$. The resonance has been observed at $77^{\circ} \mathrm{K}$ over a concentration range from $\mathrm{x}=.25$ to $\mathrm{x}=2.6$ and at room temperature over a smaller concentration range. The resonance frequency for ${ }^{71} \mathrm{Ga}$ at $77^{\circ} \mathrm{K}$ reaches a maximum at about $\mathrm{x}=1.5$ of $30.0 \mathrm{MHZ}$ (in zero applied field) corresponding to a hyperfine field of about 2.3 tesla (23 kilogauss). The resonance is from nuclei of ions on (d) sites and the hyperfine field is believed to arise from an unpaired spin density on the gallium ion which is coupled strongly with nearest neighbor iron ions. Gallium ions on (d) sites have eight nearest neighbors ( 4 neighbors on (a) sites and 4 on (d) sites) and the resonance is particularly interesting because the concentration dependence allows us to separate out the sign and magnitude of the contribution to the field from iron ions on (a) and (d) sites.

Polymorphism of $\mathrm{ABO}_{3}$-type rare earth borate solid solutions, R.S. Roth, J. L. Waring, and E.M. Levin, (Proc. Third Rare Earth Research Conf., Apr. 2-24, 1963), Book, Rare Earth Research, Chapter on Structure of Rare Earth Compounds, pp. 1030-1055 (Gordon and Breach Science Publ., Inc., New York, N.Y., 1964).

Polymorphic relations of solid solutions of the $\mathrm{ABO}_{3}$-type rare earth borates have been studied by means of quenching techniques and high temperature X-ray diffraction. It has 
been found that the polymorph reported as the high temperature form of $\mathrm{MdBO}_{3}$ (Levin, Roth, and Martin, 1961) is only metastable and is formed, on cooling, from a phase isostructural with $\mathrm{H}-\mathrm{LaBO}$. The similar polymorph of $\mathrm{SmBO}_{3}$ is apparently stable from room temperature to about $1065^{\circ} \mathrm{C}$. The high vaterite form of $\mathrm{SmBO}_{3}$ is stable from about $1065^{\circ}$ to $1285^{\circ}$ and the $\mathrm{H}-\mathrm{LaBO}_{3}$ type from $1285^{\circ}$ to the melting point. Phase equilibrium diagrams have been constructed for the systems involving $\mathrm{LaBO}_{3}$ with many of the other $\mathrm{RBO}_{3}$ compounds and for $\mathrm{NdBO}_{3}-\mathrm{SmBO}_{3}$. The aragonite and vaterite type structures are not stable in the central portion of most of these systems. Instead, the $\mathrm{H}-\mathrm{LaBO}_{3}$ and $\mathrm{L}-\mathrm{SmBO}$-type phases appear as the stable polymorphs. The $\mathrm{H}$-LaBO $\mathrm{BO}_{3}$-type polymorph is a low symmetry distortion of a calcite type structure. As smaller ions are added in solid solution to $\mathrm{LaBO}_{3}$ the distortion becomes less until with LaLo $\left(\mathrm{BO}_{3}\right)_{2}$ an hexagonal phase is formed which may have a dolomite type structure, although the super-structure peaks are not evident. However, this phase apparently disorders to a $\mathrm{H}-\mathrm{LaBO}_{3}$ type solid solution rather than to the true calcite type structure. Although the temperature of the high-low inversion of the vaterite-type structures is lowered by the addition of $\mathrm{LaBO}_{3}$ in solid solution, in no case has the high-vaterite structure been obtained at room temperature.

Optically pumped magnetometers and related experiments in high magnetic fields, P. L. Bender, Book, Quantum Electronics, Ed. P. Grivet and N. Bloembergen, III. I, 263-273 (Columbia University Press, New York, N.Y., 1964).

Some considerations on optically pumped magnetometers are given. Related experiments in high magnetic fields giving alkali nuclear moments and departures from the Breit-Rabi formula are suggested.

Hydrogen atom addition to solid four-carbon olefins, R. Klein and M. D. Scheer, J. Phys. Chem. 67, 1874-187y (Sept. 1963). An investigation of the hydrogen atom addition to condensed, solid, four-carbon olefins in the $77^{\circ} \mathrm{K}$ region has shown that the general reaction is terminal hydrogen atom addition to terminal double bonds followed by disproportionation and recombination of the resulting radicals. $H$ atoms also react with the hydrocarbon radical in a similar manner. All of the butene- 2 formed from butene- 1 and from butadiene-1,3 is trans, but that formed from butadiene- 1,2 is both cis and trans. Butadiene-1,3 produces nine eight-carbon dimers, butadiene-1,2, three, and isobutene, none. One of the major products of the $\mathrm{H}$ atom addition reaction with butadiene-1,2 is butyne- 2 .

Anomalous transmission of rare gases for electrons of subexcitation energies, J. A. Simpson, Proc. Third Intern. Conf. Physics of Electronic and Atomic Collisions, London, England, 1963, pp. 128-134 (North Holland Publ. Co., Amsterdam, The Netherlands, 1964).

Electrons of variable energy $\left(\Delta E_{1 / 2} \sim 0.05 \mathrm{eV}\right)$ are passed through a chamber containing rare gas at a pressure of some microns. Electrons which are deflected less than $40 \mathrm{mr}$ are energy analyzed (resolution $\sim 0.05 \mathrm{eV}$ ) and collected. Two types of transmission anomalies, with energy widths essentially instrumental, are observed at energies below those necessary to excite the atom. The first, in $\mathrm{He}$ at $19.1 \pm 0.1$ $\mathrm{eV}$, is an enhanced transmission followed by a decrease in a typical dispersion line shape. The second anomaly in Ne at $15.9 \pm 0.15 \mathrm{eV}$, is not so strong and has a more complicated structure consisting of a doublet ( $\sim 0.1 \mathrm{eV}$ separation). Both components are sharp decreases in transmission without dispersion line shape. A brief description of the apparatus is included.

Electron microscopy and diffraction of aluminum oxide whiskers, D. J. Barber, Phil. Mag. 10, No. 103, 75-94 (July 1964).

Whiskers of $\alpha-\mathrm{Al}_{2} \mathrm{O}_{3}$ have been grown by the condensation and oxidation of aluminium on an alumina substrate, and examined by transmission electron microscopy and diffraction. Unbroken whiskers invariably terminate in a small globule of aluminium and have a 'drumstick' form. The most perfect whiskers are ribbons with their principal surfaces parallel to the (0001) planes; the majority of these have a
$1120>$ growth direction. With intense heating in the electron beam, such ribbons can be thermally etch pitted. Many drumsticks are tubular rather than ribbonlike and drumsticks containing axial dislocations have also been seen. The effect of intense heating on these whiskers has been investigated. Occasionally, the aluminium globules melt and react with the carbon support film in the microscope to give crystalline $\mathrm{Al}_{4} \mathrm{C}_{3}$. Alternatively, a globule may explode to form many small globules that immediately develop stems; thus, new whiskers are formed in the microscope. The relevance of these observations to proposed mechanisms for the growth of drumstick whiskers is discussed.

The crystal structure of 1-ethyldecaborane, A. Perloff, Acta Cryst. 17, 332 (196.4).

Direct evidence for the existence of 1-ethyldecaborane has been established by a single crystal X-ray structure analysis using, in part, the method of direct phase determination developed by Karle and Hauptman. The compound crystallizes in the orthorhombic system with $a=10.11 \pm 0.01$, $b=14.40 \pm 0.01$, and $c=7.28 \pm 0.01 \AA$. The space group is $\mathrm{P} 2_{1} 2_{1} 2_{1}$ and the unit cell contains four molecules of $\mathrm{B}_{10} \mathrm{H}_{13} \mathrm{C}_{2} \mathrm{H}_{5}$. The compound is a simple substitution derivative of decaborane and no significant distortion of the decaborane molecule is induced by the substitution.

Optically observed inner shell electron excitation in neutral $\mathbf{K r}$ and Xe, K. Codling and R. P. Madden, Phys. Rev. Letter 12, No. 4, 106-107 (Jan. 1964).

The far ultraviolet continuum radiation emitted by the N.B.S. $180 \mathrm{Mev}$ electron synchrotron has been used for the study of the absorption spectra of $\mathrm{Kr}$ and $\mathrm{Xe}$ in the 120-200A spectral region. Structure involving transitions to neutral atom energy levels has been observed for the first time at energies in excess of $50 \mathrm{ev}$ above the 1st ionization limits of $\mathrm{Kr}$ and Xe. These transitions involve the excitation of inner shell d electrons and result in two series for each element, namely $3 d^{10} 4 s^{2} 4 p^{6}{ }^{1} \mathrm{~S}_{0}-3 d^{9} 4 s^{2} 4 p^{6}\left({ }^{2} \mathrm{D}_{3 / 2}, 5 / 2\right) \quad n p{ }^{1} \mathrm{P}^{\circ}{ }_{1}$ in $\mathrm{Kr}$, and $4 d^{10} 5 s^{2} 5 p^{6}{ }^{1} \mathrm{~S}_{0}-4 d^{9} 5 s^{2} 5 p^{6}\left({ }^{2} \mathrm{D}_{3 / 2}, 5 / 2\right) n p{ }^{1} \mathrm{P}^{\circ}{ }_{1}$ in $\mathrm{Xe}$.

Dielectric polarizability of fluid parahydrogen, J. W. Stewart, J. Chem. Phys. 40, 3297-3306 (June 1964).

The dielectric constant of liquid and gaseous para-hydrogen has been measured by the capacitance ratio method between $24^{\circ} \mathrm{K}-100^{\circ} \mathrm{K}$ and $2-326$ atmospheres. This encompasses the density range $0.002-0.080 \mathrm{gm} / \mathrm{cm}^{3}$. These data have been combined with recently available PVT results in order to calculate the Clausius-Mosotti function to $0.05 \%$ precision. In the range considered, the $\mathrm{C}-\mathrm{M}$ function, or polarizability, instead of being constant, initially rises with density to a maximum $0.2 \%$ above the low density value of $1.00427 \mathrm{~cm}^{3} / \mathrm{gm}$, and then falls. The data in this range can be represented to within experimental error by a quadratic function of density. The deviation from constancy is too small for detailed correlation with existing theories of polariz ability to be feasible. The results are presented in tabular form. Also the dielectric constant at any desired densit $y$ can easily be calculated to an accuracy better than $0.1 \%$ in $\epsilon-1$ from the function fitting the polarizability.

Standard potential of the $\mathbf{A g}-\mathbf{A g C l}$ electrode in $5 \%$ aqueous mannitol, R. Gary and R. A. Robinson, J. Chem. Eng. Data 9, No. 3, 376-378 (July 1964).

The standard potential of the $\mathrm{Ag}-\mathrm{AgCl}$ electrode from $0^{\circ}$ to $60^{\circ}$ has been determined by e.m.f. measurements on the cell: $\mathrm{Pt} / \mathrm{H}_{2}: \mathrm{HCl}(\mathrm{m})$ in $5 \%$ mannitol; $\mathrm{AgCl} / \mathrm{Ag}$. From these data and from data on the same cell containing no mannitol, the relative partial molal quantities $\Delta \overline{\mathrm{G}}^{\circ}, \Delta \overline{\mathrm{H}}^{\circ}$ and $\Delta \overline{\mathrm{S}}^{\circ}$ for the change in solvent are calculated. The value of $\Delta \overline{\mathrm{G}}^{\circ}$ for $\mathrm{HCl}$ in $5 \%$ mannitol at $25^{\circ}$ is found to be $54.0 \mathrm{j}$. mole ${ }^{-1}$. There is a small but significant change in the e.m.f. of the cell if mannitol is replaced by its diastereoisomer, sorbitol.

Optical investigations of fllm formation and removal on gold anodes in acidic oxalate solutions, W. E. Reid and J. Kruger, Nature 203, No. 4943, 402 (July 25, 1964).

Evidence has been obtained for film formation on gold anodes in acidic oxalate solutions using ellipsometry. The thickness 
of the film increases linearly with the potential above 1.1 $\mathrm{V}(\mathrm{NHE})$ in $1 \mathrm{M} \mathrm{H}_{2} \mathrm{SO}_{4}$ and solutions of low oxalate content $(4 \mathrm{~g} / \mathrm{l})$ to give a thickness of about $20 \mathrm{~A}$. The film is reduced at potentials below $1.1 \mathrm{~V}$ and also by acidic oxalate solutions. Optical evidence indicates that this film is more likely to be an oxide film rather than chemisorbed oxygen.

Recently discovered autoionizing states of krypton and xenon in the $\lambda$ 380-600A, R. P. Madden and K. Codling, J. Opt. Soc. Am. 54, No. 2, 268-269 (Feb. 1964).

The far ultra-violet continuum radiated by the NBS 180 Mev electron synchrotron has been utilized for the study of the absorption spectra of krypton and xenon in the wavelength region $380-600 \AA$. Many new autoionizing states in both elements, lying 10-40 ev above the first ionization limit, have been discovered. The following series have been identified: $4 s^{2} 4 p^{6}{ }^{1} \mathrm{~S}_{0}-4 g 4 p^{6} n p^{1} P_{1}{ }^{0}$ and $4 s^{2} 4 p^{6}{ }^{1} \mathrm{~S}_{0}-4 s^{2} 4 p^{4} 5 s n p^{1} P_{1}{ }^{0}$ in krypton, $5 s^{2} 5 p^{6}{ }^{1} \mathrm{~S}_{0}-5 s 5 p^{0} n{ }^{1} \mathrm{P}_{1}$ in xenon.

“U-spin equalities" and octet symmetry breaking, S. Meshkov, G. A. Snow, and G. B. Yodh, Phys. Rev. Letters 13, No. 6, 212-217 (Aug. 10, 1964).

The "U-Spin equalities" are compared with experiment, in order to see to what extent the $\mathrm{SU}_{3}$ predictions are obeyed. Deviations from pure $\mathrm{SU}_{3}$ symmetry by an order of magnitude are found. The role of symmetry breaking in the interaction matrix elements is investigated and correlated with the possible appearance of superresonances.

Electrode potentials in fused systems. VII. Effect of ion size on membrane potentials, K. H. Stern and J. A. Stiff, J. Electrochem. Soc. III, No. 8, 893-897 (Aug. 1964).

Concentration cells exhibiting glass membrane potentials have been measured for the $\mathrm{AgBr}-\mathrm{NaBr}, \mathrm{AgCl}-\mathrm{KCl}$, and $\mathrm{AgCl}-$ $\mathrm{CsCl}$ systems. Only for the first of these can the bulk composition be used to calculate cation transport numbers in the membrane. For the latter two the sodium ion impurities in the melt appear to be potential determining. In the sodiumcontaining systems the anions appear to be transported as part of a cationic silver complex.

On the identity of three generalized master equations, $R$. Zwanzig, Physica 30, 1109-1123 (1964).

Three apparently different quantum mechanical master equations, derived by Prigogine and Resibois, by Montroll, and independently by Nakajima and by Zwanzig, are shown to be identical. The derivation by Zwanzig, based on projection operator and Liouville operator techniques, is repeated in greater detail than in previous articles. The results of Prigogine and Resibois, and of Montroll, are found by making changes in notation.

The oxide films formed on copper single crystal surfaces in water. III. Effect of light, J. Kruger and J. P. Calvert, J. Electrochem. Soc. III, No. 9, 1038-1041 (Sept. 1964).

Studies of the effect of illumination on the growth of oxide films on copper single crystal surfaces immersed in water containing different amounts of dissolved oxygen reveal that while illumination has little effect on the oxidation process when the water is in equilibrium with a $100 \%$ oxygen atmosphere, it does lower the rate of film formation when the water is in equilibrium with $1 \%$ oxygen. For both the (111) and (100) illumination causes a departure from the rate law observed for oxidation in the dark. At intensities of $290 \mu \mathrm{w} / \mathrm{cm}^{2}$ or higher the film formed on the (111) never grows beyond a limiting thickness of $100 \AA$. The behavior observed can be explained on the basis of a competition between growth and dissolution reactions, the dissolution reaction being promoted by illumination.

Thermodynamics of aqueous solutions of hydriodic acid from electromotive force measurements of hydrogen-silver iodide cells, H. B. Hetzer, R. A. Robinson, and R. G. Bates, J. Phys. Chem. 68, No. 7, 1929-1939 (1964).

Electromotive force measurements of the cell $\mathrm{Pt} ; \mathrm{H}_{2}(\mathrm{~g})$, $\mathrm{HI}(\mathrm{m}), \mathrm{AgI} ; \mathrm{Ag}$ have been made at 11 temperatures from
0 to $50^{\circ}$. The standard e.m.f. $\left(E^{\circ}\right)$ is given within $0.05 \mathrm{mv}$. by the equation $E^{\circ}=-0.15242-3.19 \times 10^{-4}(t-25)-2.84 \times$ $10^{-6}(t-25)^{2}$, where $t$ is the temperature in degrees Celsius. These values are in excellent agreement with those obtained by Owen from studies of borax-buffered KI solutions at 5, 10, 30,35 , and $40^{\circ}$ but differ by 0.14 to $0.17 \mathrm{mv}$. at 15,20 , and $25^{\circ}$. The activity coefficient $\left(\gamma_{ \pm}\right)$of HI at molalities $(m)$ from 0.005 to 0.9 has been derived. The relative partial molal enthalpy $\left(\mathrm{L}_{2}\right)$ of $\mathrm{HI}$ at $25^{\circ}$ was calculated and compared with that for $\mathrm{HCl}$ and $\mathrm{HBr}$. At $25^{\circ}$ and $m=0.1, \gamma_{ \pm}$is 0.811 and $\mathrm{L}_{2}$ is 130 cal. mole ${ }^{-1}$.

\section{Other NBS Publications}

\section{J. Res. NBS 68B (Math. and Math. Phys.), No. 4 (Oct.-Dec. 1964), 75 cents.}

Hydrodynamic fluctuations and Stokes' Law friction. R. Zwanzig. (See above abstracts.)

Equivalence of certain inequalities complementing those of Cauchy-Schwarz and Hölder. J. B. Diaz, A. J. Goldman, and F. T. Metcalf.

Weak generalized inverses and minimum variance linear unbiased estimation. M. Zelen and A. J. Goldman.

Improvement of bounds to eigenvalues of operators of the form T.*T. N. W. Bazley and D. Fox.

The greatest crossnorm. R. Schatten.

Radio Sci. J. Res. NBS/USNC-URSI, 69D, No. 1 (Jan. 1965), $\$ 1.00$

Some problems of ionospheric nonlinearities. D. H. Menzel. Some nonlinear phenomena in the ionosphere. V. A. Bailey. An experimental study of gyro interaction in the ionosphere, at oblique incidence. F. H. Hibberd.

On some nonlinear phenomena in the ionospheric plasma. P. Caldirola and O. De Barbieri.

Ionospheric cross modulation: a microscopic theory. D. Layzer and D. H. Menzel.

VLF noise bands observed by the Alouette I satellite. J. S. Belrose and R. E. Barrington.

Excitation of optical radiation by high power density radio beams. L. R. Megill.

Alteration of the electron density of the lower ionosphere with ground-based transmitters. P. P. Lombardini.

Collision effects in hydromagneto-ionic theory. H. K. Sen and A. A. Wyller.

Electromagnetic wave reflection from an oscillating, collisionfree magneto-ionic medium. O. E. H. Rydbeck.

Nonlinear propagation of electromagnetic waves in magnetoplasmas. II. (An invited abstract) M. S. Sodha and C. J. Palumbo.

Standard X-ray diffraction powder patterns, H. E. Swanson, M. C. Morris, E. H. Evans, and L. Ulmer, NBS Mono. 25-Sec. 3 (July 31, 1964), 40 cents.

Hydraulic Research in the United States 1964, Ed. H. K. Middleton, NBS Misc. Publ. 261 (Aug. 14, 1964), \$1.25.

Water-repellent preservative non-pressure treatment for millwork, CS262-63 (Dec. 31, 1963), 10 cents.

Quarterly radio noise data March, April, May 1963, W. Q. Crichlow, R. T. Disney, and M. A. Jenkins, NBS Tech. Note 18-18 (July 25, 1964), 50 cents.

A helicopter battery service simulator, W. G. Eicke, Jr., NBS Tech. Note 244 (Aug. 28, 1964), 20 cents.

Factors influencing the design of original-document scanners for input to computers, NBS Tech. Note 245 (Aug. 19, 1964), 35 cents.

Radiochemical analysis: Activation analysis, instrumentation, radiation techniques, and radioisotope techniques, Ed. J. R. DeVoe, NBS Tech. Note 248 (Aug. 21, 1964), 50 cents.

Tooth fluorometer, A. F. Forziati, J. Kumpula, and J. J. Barone, J. Am. Dental Assoc. 67, No. 5, 663-669 (Nov. 1963).

Thermodynamic representation of high-pressure vaporliquid equilibria, J. M. Prausnitz, Chem. Eng. Sci. 18, 613630 (1963).

Nuclear magnetic relaxation of the impurity nucleus in dilute 
ferromagnetic alloys, R. L. Streever, Phys, Rev. 134, No. 6A, A1612-A1617 (June 15, 1964).

NBS microcopy resolution test chart, B. H. Fouquet, Proc. Natl. Microfilm Association Meeting, San Francisco, Calif., Apr. 30-May 13, 1963, pp. 67-74 (1963).

Metastable transitions in mass spectra of methane and the deuteromethanes, V. H. Diebeler and H. M. Rosenstock, J. Chem. Phys. 39, 1326 (1963).

Electron distribution in the ionosphere, J. W. Wright, Proc. URSI XIVth General Assembly, Sept. 1963, Tokyo, Japan XIII, 206-222 (1964).

Studies at NBS of the platinum-6\% rhodium vs. platinum$30 \%$ rhodium thermocouple-A preliminary report, G. W. Burns, Proc. SAE Meeting, Sept. 23-27, 1963, Los Angeles, Calif., Preprint 750B, (1963).

Spread- $F$ observations by the Alouette topside sounder satellite, W. Calvert and C. W. Schmid, J. Geophys. Res. 69, No. 9, 1839-1852 (May 1, 1964).

Spectral distribution of typical daylight as a function of correlated color temperature, D. B. Judd, D. L. MacAdam, and G. Wyszecki, J. Opt. Soc. Am 54, No. 8, 1031-1040 (Aug. 1964).

Medical applications of refrigeration, E. F. G. Brentari and R. V. Smith, ASHRAE Guide and Data Book, ch. 68, 773-778 (Am. Soc. Heating, Refrig. Air Conditioning Engrs., Inc., New York, N.Y., 1964).

Measuring the directivity of a directional coupler using a sliding short-circuit and an adjustable sliding termination, R. W. Beatty, IEEE Trans. Microwave Theory Tech. MTT-12, No. 3,283 (May 1964).

Mass spectrometric study of the photoionization of acetylene and acetylene- $d_{2}$, V. H. Dibeler and R. M. Reese, J. Chem. Phys. 40, No. 7, 2034-2035 (Apr. 1, 1964).

Magnetically retained evaporation mask, F. E. Jones and A. B. Castle, Sr., Rev. Sci. Instr. 34, No. 9, 1055 (Sept. 1963).

Low-temperature infrared studies of the chemistry of free radicals, M. E. Jacox and D. E. Milligan, Appl. Opt. 3, 873 (July 1964).

Characteristics of energy losses of electrons in solids, L. Marton, Book, Actions Chimiques et Biologiques Des Radiations, ch. IV, pp. 260-281 (Masson et Cie Editeurs, Paris, France, 1964).

Isotopic fractionation of uranium related to roll features in sandstone, Shirley Basin, Wyoming, J. N. Rosholt, E. N. Harshman, W. R. Shields, and E. L. Garner, Econ. Geology 59, 570 (1964).

Book, Thermal Degradation of Organic Polymers, S. L. Madorsky (Interscience Publ. Inc., New York, N.Y., 1964).

Solid state detector for beta-ray spectroscopy below $4.2^{\circ}$, K. J. Chin, A. T. Hirshfeld, and D. D. Hoppes, Rev. Sci. Instr. 34, No. 12, 1258-1259 (Nov. 1963).

Simple derivation of the Faxen solution to the Lamm equation, G. H. Weiss, J. Math, Phys. 5, No. 5, 675-676 (May 1964).

Should the convention definition of mismatch loss be abandoned? K. A. Norton, Proc. IEEE 52, 710 (June 1964).

Frequency and time standards, G. E. Hudson, Electronics World \%2, 20-23 (Aug. 1964).

Recognition of clauses in machine translation of languages, F. L. Alt, Proc. Intern. Conf. Machine Translation of Languages and Applied Language Analysis, Teddington, England Symp. No. 13, pp. 126-142 (Her Majesty's Stationery Office, London, England, Sept. 1961).

X-ray study of a cadmium borate glass, S. Block, J. Molin, and J. Piermarini, J. Am. Ceram. Soc. 46, 557 (1963).

World days program, A. H. Shapley, IQSY Notes 5, 27-30 (Dec. 1963) ; 6, 27-32 (Mar. 1964); 7, 13-15, (May 1964).

Weights and measures and aerosols, M. W. Jensen, Proc. 50th Annual Meeting of Chemical Specialties Manufactures Association, pp. 33-35 (Dec. 9-12, 1963).

Transequatorial reception of a very-low-frequency transmission, C. J. Chilton, A. Diede, and S. Radicells, J. Geophys Res. 69, No. 7, 1319-1328 (Apr. 1, 1964).

Tomorrow's facilities for standards and measurement, H. F. Wollin, Scale J. 50, No. 6, 2 (Mar. 1964).

Review of recent developments of high temperature thermocouples, P. D. Freeze, Am. Soc. Mech. Engrs., Paper No. 63-Wa, 212, 16 (Nov. 1963).
Effects of magnetic disturbance as noted on oblique incidence ionograms, V. Agy and K. Davies, AGARDograph 59, The effect of disturbances of solar origin on communications, Ed. G. J. Gassmann, pp. 167-176 (Pergamon Pres, Inc., London, England, 1963).

Editorial, R. W. Beatty, IEEE Trans. Microwave Theory Tech. MTT-12, No. 3, 274 (May 1964).

Comparison calibration of inductive voltage dividers, R. V. Lisle and T. L. Zapf, ISA 1963 Proc. Paper 7.1.63 (1963).

Correction to a method for measuring the directivity of directional couplers, G. E. Schafer and R. W. Beatty, IEEE Trans. Microwave Theory Tech. MTT-12, No. 3, 361 (May 1964).

Ionospheric absorption in conjugate regions and possible oscillation of the ionosphere, H. J. A. Chivers, and J. K. Hargreaves, Nature 202, 891-893 (May 30, 1964).

Inline waveguide attenuator, W. Larson, IEEE Trans. Microwave Theory Tech. Corres. Sec. MTT'-12, No. 3, 367-368 (May 1964).

Infrared spectroscopy of weak charge-transfer absorption spectra of $\mathrm{NO}$ in $\mathrm{Kr}$ and $\mathrm{CH}_{3} \mathrm{OH}$ solutions, E. E. Ferguson and H. P. Broida, J. Chem. Phys. 40, 3715 (1964).

Index to Journal of Association for Computing Machines, W. W. Youden, J. Assoc. Comp. Mach. 10, No. 4, 583-646 (Oct. 1963).

Improved transducer for external recording of arterial pulse waves, M. Davis, B. Gilmore, and E. Freis, IEEE Trans. Bio-Med. Elec. BME-10, No. 4, 173-175 (Oct. 1963).

Physical properties of cements, based on zinc oxide hydrogenated rosin, $o$-ethoxybenzoic acid and eugenol, S. Civijan and G. M. Brauer, J. Dental Res. 43, No. 2, 281-299 (Mar.-Apr. 1964).

A study of geomagnetic effects associated with auroral zone electron precipitation observed by balloons, W. H. Campbell, J. Geomagnetism and Geoelectricity 11, No. 1, 37-57 (June 1964).

On the constitution of the topside ionosphere, R. W. Knecht, H. Rishbeth, and T. E. VanZandt, (Proc. of NATO Advanced Study Inst., April 17-26, 1963, Skeikampen, Norway), Book Electron Density Distribution in Ionosphere and Exoshere, pp. 348-350 (North Holland Publ. Co., Amsterdam, The Netherlands, 1964).

On a problem of G. Sansone, M. Newman, Ann. Mat. LXV, 27-34 (1964).

A time-varying model of the ionospheric $F 2$ layer, H. Rishbeth, J. Atmospheric Terrest. Phys. 26, No. 6, 657-685 (June 1964).

The anomaly in the response of semiconductor detectors at low temperatures, W. R. Dodge, S. Domen, D. Hopper, and A. Hirshfeld, IEEE Trans. Nucl. Sci. NS-11, 1-14, (June 1964).

A theoretical study of the Martian ionosphere, R. B. Norton, Book, Advances in the Astronautical Science Exploration of Mars 15, 533-542 (Western Periodicals, California, 1963).

A new high voltage calibration facility at the National Bureau of Standards, Boulder, W. W. Scott, ISA 1963 Proc. Paper No. 7.2.63 (1963).

A low input VSWR coaxial diode switch for the UHF band, W. L. Ecklund, IEEE Trans. Microwave Theory Tech. Corres. Sec. MTT-12, No. 3, 359 (May 1964).

Suggested practices for establishing sampling and sample preparation techniques in spectrochemical analysis, R. E. Michaelis, Book, Methods for Emission of Spectrochemical Analysis, 4th Edition, pp. 256-259 (American Society for Testing Materials, Phila., Pa., Feb. 1964).

S-wave hyperon-nucleon interactions and $\mathrm{SU}_{3}$ symmetry, P. D. DeSouza, G. A. Snow, and S. Meshkov, Phys. Rev. 135, p. 565 (1964).

Synthesis of higher ketoses by aldol reactions, II. Unsubstituted heptuloses, R. Schaffer, J. Org. Chern. 29, 1471-1475 (June 1964).

Excess entropy at glass transformation, A. B. Bestul and S. S. Chang, J. Chem. Phys. 40, 3731 (1964).

The large $50 \mathrm{Mc} / \mathrm{s}$ dipole array at Jicamarca Radio Observatory, G. R. Ochs, Digest of the 1963 IEEE Professional Groupon Antennas and Propagation p. 237 (July 1963). 
The ionosphere and radio propagation in the lower frequencies (a report of an AGU session by the same title) $\mathrm{T} . \mathrm{N}$. Gautier, Science 143, No. 3611, 1197-1199 (Mar. 13, 1964).

Numerical analysis of the thermal environment of occupied underground spaces with finite cover using a digital computer, T. Kusuda and P. R. Achenbach, ASHRAE Trans. 6, No. 6, 99-105 (June 1964).

A diffusive model for the initial phase of a solar proton event, G. C. Reid, J. Geophys. Res. 69, 2659-2667 (June 1964).

Emission spectrometry, B. F. Scribner and M. Margoshes,

Anal. Chem. 36, No. 5, 329-343R (1964).

Elementary derivation of time-correlation formulas for transport coefficients, R. Zwanzig, J. Chem. Phys. 40, No. 9, 2527-2533 (May 1964).

A complete description of the normal subgroups of genus one of the modular group, M. Newman, Am. J. Math, 86, 17-24 (1964).

Abbreviated Calendar record, January-February 1964, A. H. Shapley, IQSY Notes 7, 19-25 (May 1964).

Evidence for a cooperative intramolecular transition in poly-L-proline, F. Gornick, L. Mandelkern, A. F. Diorio, and D. E. Roberts, Am. Chem. Soc. 86, No. 13, 2549-2555 (July 1964).

The isomerization of D-manno-3-heptulose by alkali, R. Schaffer, J. Org. Chem. 29, 1471-1475 (June 1964)

Insertion loss concepts, R.-W. Beatty, Proc. IEEE 52, 663671 (June 1964).

Reaction rates for the formation of $\mathrm{He}_{2}+$ and $\mathrm{Ne}_{2}+$, E. C. Beaty and P. L. Patterson, Book, Comptes Rendus de la VI ${ }^{\mathrm{e}}$ Conference Internationale sur les Phenomenes D'Ionisation dans les Gaz, Ed. P. Hubert and E. Cremieu-Alcan III, pp. 289-293 (S.E.R.M.A. Publ. Co., Paris, France, 1963).

Ranking laboratories and evaluating methods of measurement in round-robin tests, T. W. Lashof, Mater. Res. Std. 4, No. 8, 397-407 (Aug. 1964).

Projection X-ray microscopy of roofing materials, S. B. Newman and S. H. Greenfeld, Mater. Res. Std. 3, No. 11, 893-898 (Nov. 1963).

Polarography as an analytical tool, J. K. Taylor, J. Assoc. Offic. Agri. Chem. 4\%, No. 1, 21-27 (Jan. 1964).

Polar-cap absorption, D. K. Dailey, Planetary Space Sci. 12, 495-541 (May 1964).

Polymorphism in isopropyl alcohol, G. S. Ross, H. L. Dixon, L. Frolen, and D. J. Termini, Science 141, No. 3585, 1043-1044 (Sept. 1963).

Changes in relation between refractive index and Young's modulus as the result of successive heat treatment, E. H. Hamilton, J. Am. Ceram. Soc. 47, No. 4, 167-170 (Apr. 1964)

Characteristics of programs for KWIC and other computerproduced indexes, W. W. Youden, (Proc. American Documentation Institute Annual Meeting, Oct. 1963) Book, Automation \& Scientific Communication, pp. 331-332 (H. T. Luhn, Am. Documentation Inst., 1963).

Plastics, G. M. Klein, The 1964 Americana Annual, p. 532 (Americana Corp., Chicago, Ill., 1964).

Oxygen atom reactions with condensed olefins, M. D. Scheer and R. Klein, Science 144, No. 3623, 1214 (Apr. 1964).

Bound states in a Debye-Hueckel potential, C. R. Smith, Phys. Rev. 134, A1235-A1237 (June 1964).

The units and standards of electrical measure, F. K. Harris, Electron World $\boldsymbol{7}$, No. 2, 29-32 (Aug. 1964.)

Tetragonal phases of the general type $10 \mathrm{M}_{2} \mathrm{O}_{5} \cdot 90 \mathrm{M}_{2} \mathrm{O}_{5}$ apparently isostructural with $\mathrm{Ta}_{2} \mathrm{O}_{5} \cdot 2 \mathrm{~N}_{\mathrm{b}} \mathrm{O}_{5}, J$. L. Waring and R. S. Roth, Acta Cryst. 17, 455-456 (1964).

Ionizing radiation and constitution of the atmosphere, T. E. VanZandt, Proc. URSI XIVth General Assembly, Sept. 1963 Tokyo, Japan XIII, 158-164 (1964).

Interpretation of frequency shifts due to electron exchange collisions, P. L. Bender, Phys. Rev. 134, No. 5A, A1174 A1180 (June 1, 1964)

International Geophysical Calendar for the years of the Quiet Sun 1964-1965, A. H. Shapley and J. V. Lincoln, J. Radio Res. Lab., Japan 10, 185-192 (Mar. 1963); IUGG Chronicle 50, 171-174 (July 1963); URSI Inform. Bull. 139, 64-71 (July-Aug. 1963); IGY Bull. 94, 15-18 (Aug. 1963); Weatherwise 16, 160-161 (Aug. 1963); J. Geophys Res. 68, 5318-5323 (Sept. 1963); Trans. Ám.
Geophys. Union 44, 821-824 (Sept. 1963); J. Atmospheric Terrest. Phys. 26, No. 1, 151-157 (Jan. 1964); Nature 201, 11-13 (Jan. 4, 1964).

International Geophysical calendar 1963, A. H. Shapley and J. V. Lincoln, IQSY Notes 4, 34 (Sept. 1963).

Internal friction in rutile containing point defects, J. B. Wachtman, Jr., and L. R. Doyle, Phys. Rev. 135A, 276, (1964).

Instant color correction, C. S. McCamy, Modern Photo. 28, No. 1, 66-67 (Jan. 1964).

Review of static seals for cryogenic svstems, R. F. Robbins and P. R. Ludtke, J. Spacecraft Rts 1, No. 3, 253-259 (May-June 1964).

Resurgence of solar and geomagnetic activity in September and October 1963, A. H. Shapley, IQSY Notes 5, 10, (Dec. 1963).

Dose fields from plane sources using point source data, J. H, Hubbell, Nucleonics 21, No. 8, 144-148 (Aug. 1963).

Diurnal and seasonal variations of the atmosphere near the 100-kilometer level, J. W. Wright, J. Geophys. Res. 69, 2851-2853 (June 1964).

D-region electron density profiles during auroras, G. M. Lerfald, C. G. Little, and R. Parthasarathy, J. Geophys. Res. 69, 2857-2860 (June 1964).

Binary error probability due to an adaptable fading model, M. Nesenbergs, IEEE Trans. Comm. Systems CS-12, No. 1, 64-73 (Mar. 1964).

An X-ray determination of the Debye temperature of silver iodide, G. Burley, J. Phys. Chem. Solids 25, 629 (1964).

HF propagation characteristics in equatorial latitudes, A. Barghausen, G. Jacobs, and D. Lillie, Program \& Digest of IEEE Trans. Ant. Prop. Intern. Symp. July 9-11, 1963, Boulder, Colo., pp. 37-42 (IEEE, New York, N.Y. 1963). Hall generators: what, why, and how much?, S. Rubin, 1964 IEEE Intern Convention Record, Part 8, p. 74 (Mar. 1964). The half-life of carbon-14: Comments on the mass-spectrometric method E. E. Hughes and W. B. Mann, Intern. J. Appl. Rad. Isotopes 15, No. 1, 97-100 (Jan. 1964).

A unitary symmetry selection rule and its application to new resonances, C. A. Levinson, H. J. Lipkin, and S. Meshkov, Il Nuovo Cimento 32, Ser. X, 1376-1379 (1964).

A recalibration of the National Bureau of Standards tritiated water standards by gas counting, W. B. Mann, R. W. Medlock, and O. Yura, Intern. J. Appl. Rad. Isotopes 15, No. 6, 351-361 (1964).

The guided propagation of ELF and VLF radio waves between the earth and the ionosphere, D. D. Crombie and A. G. Jean, Proc. URSI XIVth General Assembly, Sept, 1963, Tokyo, Japan XIII, 195-206 (1964).

Electronic scanning for large radiotelescopes, T. A. Clark, Digest of 1963 IEEE Professional Group on Antennas and Propagation, pp. 242-246 (July 1963).

The excitation of the $2 \mathrm{P}$ state of hydrogen by electrons of near-threshold energy, G. E. Chamberlain, S. J. Smith, and D. W. O. Heddle, Phys. Rev. Letters 12, No. 23, 647-649 (June 8, 1964).

Theory of operation of the rotary positive displacement meter, C. T. Collett (Proc. 23d Annual Gas Measurement Short Course, Aug. 20, 1963), West Virginia Univ. Tech. Bull. 70, 48-53 (1963)

The zeros of infrapolynomials with prescribed values at given points, J. L. Walsh and O. Shisha, J. Math. Anal. Appl. 7, No. 2, 176-182 (Oct. 1963).

The establishment and maintenance of the unit of voltage at the NBS Boulder Laboratories, B. A. Wickoff, ISA 1963 Proc. Paper No. 28.2.63 (1963).

On the production of the $\mathrm{Z}^{-}\left(\Omega^{-}\right)$Baryon, H. J. Lipkin, C. A. Levinson, and S. Meshkov, Phys. Letters \%, No. 2, 159-161 (Nov. 1, 1963).

On the implication of diurnal, seasonal and geographical variations in composition of the high atmosphere from $F$-region measurements, J. W. Wright, J. Geophys. Res. 68, No. 19, 5413-1520 (Oct. 1, 1963); Book, Electron Density Distribution in Ionosphere and Exosphere (Proc. of NATO Advances Study Institute, April 17-26, Sheikampen, Norway), pp. 105-115 (North Holland Publ. Co., Amsterdam, The Netherlands, 1963).

On the effect of heterogeneity in molecular weight on the sedimentation equilibrium second virial coefficient of polymers 
in good solvents, I. H. Billick, J. Phys. Chem. 68, No. 7, 1798-1800 (July 1964).

A symmetry group containing both the Lorentz group and $\mathrm{SU}_{3}$, A. O. Brant, Il Nuovo Cimento 32, 234-236 (Apr. 1964).

Four-point probe measurement of non-uniformities in semiconductor sheet resistivity, L. H. Swartzendruber, Solid State Electronics $\boldsymbol{\gamma}, 413-422$ (1964).

The use of dual-polarized broad beam antennas to determine the extraterrestrial intensity of the cosmic radio noise at high frequencies, C. G. Little, G. M. Lerfald, and R. Parthasarathy, Digest of the 1963 IRE Professional Group on Antennas and Proagation, pp. 9-15 (July 1963).

The solid state of rare gases, G. L. Pollack, Rev. Mod. Phys. 36, No. 3, 748-792 (July 1964).

The present and future of astrophysics and its effects on industry in Colorado, L. M. Branscomb, Book, Colorado and the New Technological Revolution: Proceedings of the University-Industry Liaison Conference 1963, Ed. W. H. Miernyk, pp. 55-64 (Bureau of Economic Research, Institute of Behavioral Science, Univ. of Colorado, Boulder, 1964).

A simplified freezing point apparatus, G. S. Ross and A. R. Glasgow, Jr., Anal. Chem. 36, No. 3, 700 (Mar. 1964).

Autoionization in helium using a synchrotron light source, R. P. Madden, and K. Codling Proc. VIth Intern'l Conf. of Ionization Phenomena in Gases, Paris, France 1963, V. 1, 139-143 (1963).

Radiowave scattering in the ionosphere, K. L. Bowles, Book, Advances in Electrons and Electron Physics 19, 55-176 (1964).

Radio, the ionosphere, and IQSY, R. W. Knecht, Proc. URSI XIVth General Assembly, Sept. 1963, Tokyo, Japan XIII, 169-180 (1964).

Pseudopentagonal twins in electrodeposited copper dendrites, F. Ogburn, B. Paretzkin, and H. S. Peiser, Acta Cryst. 17, 774-775 (1964).

Conduction-cooled, concentric sphere glass trap, S. Ruthberg, J. Vacuum 14, No. 1, 11 (Jan. 1964).

Conductance of potassium chloride in highly purified $n$ methylpropionamide from 20 to $40^{\circ}$, T. B. Hoover, J. Phys. Chem. 68, No. 14, 876-879 (Apr. 1964).

Field measurements of air infiltration in ten electrically heated houses, C. W. Coblentz, and P. R. Achenbach, ASHRAE J. 5, No. 7, 69 (July 1963).

Discrepancy in conversion of early melting-point temperatures, S. J. Schneider, J. Am. Ceram. Soc. 46, No. 7, 354355 (1963).

Relation of solar active regions at central meridian passage to ionospheric disturbance, C. S. Warwick and J. V. Lincoln, AGARDograph 59, The Effect of Disturbances of Solar Origin on Communications, Ed. G. J. Gassmann, pp. 229233 (Pergamon Press Inc., London, England, 1963).

Report of committee E-2 on emission spectroscopy, R. E. Michaelis, Am. Soc. Testing Mater. Proc. 63, 456 (1963).

The relationship between intensity of carbon arc and asphalt oxidation, J. R. Wright, P. G. Campbell, and T. L. Fridinger, ASTM Spec. Tech. Publ. No. 347, pp. 3-20 (May 1964).

Evidence for field-aligned ionization irregularities between 400 and $1000 \mathrm{~km}$ above the earth surface, T. E. VanZandt, W. Calvert, R. W. Knecht, and G. B. Goe, Book, Space Research, Ed. W. Priester, III, 271-273 (North Holland Publ. Co., Amsterdam, The Netherlands, 1963).

Experimental predictions from unitary symmetry $\left(\mathrm{SU}_{3}\right)$, C. A. Levinson, H. V. Lipkin, and S. Meshkev, (Proc. 1963 Intern. Conf. Nucleon Structure, Stanford Univ., Calif.), Book, Nucleon Structure, p. 309 (University Press, Stanford, Calif., Aug. 1963).

Summary of symposium on recent research on bituminous materials, S. H. Greenfeld, ASTM Spec. Tech. Publ. No. 347, pp. 108-111 (May 1964).

First results in NASA topside sounder satellite, R. W. Knecht, S. Russell, and J. E. Jackson, Book, Advances in Astronautical Ściences 11, 61-85 (Western Periodicals Co., Calif., 1963).

Reaction rates for the formation of $\mathrm{He}_{2}{ }^{+}$and $\mathrm{N}_{\mathrm{e}}^{+}$, E. C. Beaty and P. L. Patterson, Book, Comptes Rendus de la VI ${ }^{\mathrm{e}}$
Conf. Intern. sur les Phenomenes d'Ionisation dans les Gaz, Ed. P. Hubert and E. Cremieu-Alcan III, pp. 289-293 (S.E.R.M.A. Publ. Co., Paris, France, 1963).

Comparisons of experimental reaction cross sections with various relations obtained from $\mathrm{SU}_{3}, \mathrm{~S}$. Meshkob, Proc. Conf. Symmetry Principles at High Energy, Coral Gables, Fla., Jan. 1964, pp. 104-126 (1964).

Very-low-frequency radio waves and the ionosphere, D. D. Crombie, Science 142, No. 3591, 508-510 (Oct. 25, 1963). Standardization of dimensions of packages for self-service selling, A. T. McPherson and A. S. Best, THE PACKET, Packaging Professional 2, No. 3, 4-5 (Packaging Inst., 1964).

Response characteristics of a $4 \pi$ neutron detector, H. Gerstenberg, Bull. Am. Phys. Soc. 9, Pt. 2, 421 (Apr. 28, 1964).

Geomagnetic and solar data, J. V. Lincoln, J. Geophys. Res. 69, No. 13, 2841 (July 1, 1964).

Spectroscopic investigations of fluorescence and chemiluminescence in gases, (collection of papers), T. Carrington, Aero-Space Research Laboratory Report No. 64-51 (Mar. 1964).

Fractionation of uranium isotopes and daughter products in weathered granite and uranium-bearing-sandstone, Wind River basin region, Wyoming, J. N. Rosholt, E. L. Garner, and W. R. Shields, U.S. Geol. Surv. Prof. Paper 501-B, pp. 884-887 (1964).

Some results of a new method for obtaining ionospheric $\mathrm{N}(\mathrm{h})$ profiles with a bearing on the structure of the lower $F$ region, J. W. Wright and A. K. Paul, J. Geophys. Res. 68, No. 19, 5413-5420 (Oct. 1, 1963); Proc. NATA Advanced Study Institute, Skeikampen, Norway, (Apr. 17-26, 1963), Book, Electron Density Distribution in the Ionosphere and Exosphere, pp. 105-115 (North Holland Publ. Co., Amsterdam, The Netherlands, 1963).

Error analysis of Miller's recurrence algorithm, R. W. J. Olver, Math. Comp. 18, No. 85, 65-74 (Jan. 1964).

$\mathrm{Sr}^{97} / \mathrm{Sr}^{96}$ ratios in Hawaiian lavas, P. Lessing and E. J. Catanzaro, J. Geophys. Res. 69, No. 8, 1599-1601 (Apr. 15, 1964).

The spheroidal method for satellite orbits, J. P. Vinti, Proc. Intern. Symp. Use of Artificial Satellites for Geodesy, pp. 12-16 (North Holland Publ. Co., Amsterdam, The Netherlands, 1963).

Opening angles of electron-positron pairs, H. Olsen, Phys, Rev. 131, No. 1, 406-415 (July 1, 1963).

Some impulse sparkover voltages for a $200 \mathrm{~cm}$ sphere gap, H. N. Cones, IEEE Component Parts Conf. Paper No. CP 63-929 (June 1963).

Determination of optical thickness gradients from a far distance, J. R. Meyer-Arendt, R. B. Herrick and C. B. Emmanuel, J. Opt. Soc. Am. 53, 1344 (1963).

Solar particles and interplanetary fields, C. S. Warwick, Book, Advances in the Astronautical Sciences 13, 666-681 (Western Periodicals, Calif., 1963).

Vaporization of uranium monophosphide, K. A. Gingerick, P. K. Lee, and J. E. Efimenko, Nature 200, No. 4908, $774-776$ (1963).

A radio-meteorological study, B. R. Bean, E. J. Dutton, V. R. Frank, J. A. Lane, and W. B. Sweezy, Program and Digest 1963 IEE Prof. Group Antennas and Propagation Symp. Space Telecommunications, July 9-11, 1963, Boulder, Colo., pp. 56-60 (1963).

The interaction of $350 \mathrm{keV}$ polarized neutrons with oriented $H_{0}{ }^{165}$ nuclei, H. Marshak, R. Wagner, P. P. Miller, and T. Tamura, Physies Letters 10, No. 3, 316 (June 15, 1964). Systematic atmospheric refraction errors of baseline type radio tracking systems and methods of their correction, G. D. Thayer and B. R. Bean, Proc. First Space Congress, Cocoa Beach, Florida (Apr. 1964).

Error bounds for asymptotic expansions in turning-point problems, F. W. J. Oliver, Soc. Ind. Appl. Math. 1, No. 1, 200-214 (Mar. 1964).

Summary of session I and II of the symposium on X-ray and electron probe analysis, R. E. Michaelis, ASTM Spec. Tech. Publ. No. 349 (Dec. 1963).

Prebunching in electron linacs, J. E. Leiss, Proc. Conf. Proton Linear Accelerators, Yale Univ., New Haven, Conn., pp. 267-273 (Oct. 1963). 
Report on standard samples, reference samples and highpurity material for spectrochemical analysis, R. E. Michaelis, ASTM Spec. Tech. Publ. No. 58-E (1963).

Phase diagrams for ceramists, Book, E. M. Levin, C. R. Robbins, and H. F. McMurdie, American Ceramic Society Inc., Columbus, Ohio (1964).

Transverse propagation of electromagnetic waves in a cylindrically stratified plasma, J. R. Wait, Proc. Radio Physics Symp., University of California, Los Angeles, Aug. 7-9, 1963, Ed. J. Brandstatter (Holden-Day, Inc., San Francisco, Calif., 1964).

Variations in phase path of man-made one-hop whistler mode signals at 18.6 kilocycles per second, D. D. Crombie, F. A. McNeill, and G. M. Allcock, J. Geophys. Res. 68, No. 23, 6229-6325 (Dec. 1, 1963).

Fluorometric demonstration of tryptophan in dentin and bone protein, K. C. Hoerman and S. A. Mancewicz, J. Dental Res. 43, No. 2, 276-280 (Mar.-Apr. 1964).

The calibration of inductive voltage dividers and analysis of their operational characteristics, T. L. Zapf, ISA Trans. 2, No. 3, 195-200 (July 1963).

Nighttime variations of $F$-region electron density profiles at Puerto Rico, T. Shimazaki, J. Geophys. Res. 69, No. 13, 2781-2797 (July 1, 1964).

Obscurities of oscillator noise, L. Fey, W. R. Atkinson, and J. Newman, Proc. IEEE Letter 52, 104-105 (Jan. 1964).

Standard electromotive force of the hydrogen-silver chloride cell and the thermodynamics of solutions of hydrochloric acid in 50 wt. $\%$ methanol from 10 to $40^{\circ} \mathrm{C}$, M. Paabo, R. A. Robinson, and R. G. Bates, J. Chem. Eng. Data 9 No. 3, 374-376 (July 1964).

The $F$-region seasonal anomaly, J. W. Wright, J. Geophys. Res. 68, No. 14, 4379-4381 (July 15, 1963).

Coherent Raman effect in the off-axis Raman resonator, $H$. Takuma and D. A. Jennings, Appl. Phys. Letters 4, No. 11, 185-186 (June 1964).

Effects of composition and irradiation on the glass transition temperature of methyl methacrylate-styrene copolymers, M. S. Parker, V. J. Krasnansky, and B. G. Acchammer, J. Appl. Polymer Sci. 8, 1825-1838 (1964).

The scope of electrochemistry, W. J. Hamer, J. Electrochem. Soc. 110, No. 6, 115C (June 1963).

Report on sugars and sugar products, E. J. McDonalds, J. Assoc. Official Agri. Chem. 46, 35 (1963).

Thermal conductivity and viscosity of simple fluids, J. V. Sengers, Am. Chem. Soc. 9, No. 4, C-57-C-70 (Sept. 1964).

Some recent developments in mobile metal thermocouples. L. O. Olsen, Am. Soc. Auto. Engrs. Paper No. 750A, p. 10 (Sept. 1963).

Gallium-palladium alloys as dental filling material, R. M. Waterstrat and R. W. Longton, Public Health Rept. 79, No. 7, pp. 638-642 (July 1964).

Minutes of the meeting at the Ohio State University, Columbus, Ohio, of the Triple Commission for Spectroscopy, June 13, 1963, C. E. Moore, J. Opt. Soc. Am. 54, No. 3, 425-432 (Mar. 1964).

High frequency microvolt measurements, F. X. Ries, ISA Preprint, pp. 37.2.63-1-37.2.63-5 (Sept. 1963).

Comparison of a new $\mathrm{SU}_{3}$ prediction with experiment, $\mathrm{S}$. Meshkov, G. A. Snow, and G. B. Yodh, Phys. Rev. Letters 12, No. 3, 87-92 (Jan. 20, 1964).
Measurement of photochemical degradation in certain plastics by color reactions with phenylenediamines, V. E. Gray and J. R. Wright, J. Appl. Polymer Sci. 8, No. 4, 1505-1519 (1964).

On Rayleigh's non-linear vibration equation, A. Ghaffari, Proc. Intern. Symp. Non-Linear Vibration II, 130-133 (Sept. 1961).

An unmodulated twin channel microwave attenuation measurement system, D. H. Russell, ISA Preprint, pp. 37.3.63-1-37.3.63-17 (Sept. 1963).

Beam loading and beam blowup in electron linacs, J. E. Leiss, Proc. Conf. Proton Linear Accelerators, Yale Univ., New Haven, Conn., pp. 74-95 (Oct. 1963).

Residual range and range rate errors due to the troposphere, E. C. Barrows, Proc. Conf. Tropospheric Refraction (Dec. 1963).

Tropospheric refraction and attenuation of radio waves, B. R. Bean, Book, Advances of Radio Research, p. 53-155 (Academic Press Inc., New York, N.Y., June 1964).

Kikuchi pattern from a silicon wedge, H. A. Fowler, Acta Cryst. 17, No. 7, 869-871 (July 1964).

On line data handling system for the National Bureau of Standards LINAC, J. Leiss, J. Broberg, R. Schrack, and J. M. Wyckoff, IEEE Trans. Nuclear Sci. NS-11, No. 3, 331-337 (June 1964).

Long-term characteristic for air-ground propagation in band nine, R. S. Kirby, Program and Digest 1963 IEEE Prof. Group Antennas and Propagation Symp. Space Telecommunications, July 9-11, 1963, Boulder, Colo., p. 43-47 (1963).

Measurement of effective temperatures of microwave noise sources, J. S. Wells, W. C. Daywitt, and C. K. S. Miller, IEEE Trans. Instr. Meas. IM-13, No. 1, 17-28 (Mar. 1964).

The turbulent characteristics of the radio refractive index near the ground, B. R. Bean and R. E. McGavin, Program and Digest 1963 IEE Prof. Group Antennas and Propagation Symp. Space Telecommunications, July 9-11, 1963, Boulder, Colo., pp. 60-64 (1963).

Use of high-strength ceramics in vibration transducers, E. Jones, J. Acoust. Soc. 36, No. 6, 1215-1216 (June 1964). Phase instability in a tropospheric relay link, E. C. Barrows, Program and Digest 1963 IEEE Prof. Group. Antennas and Propagation Symp. Space Telecommunications, July 9-11, 1963, Boulder, Colo., pp. 52-55 (1963).

Analysis of rotation errors of a waveguide rotary-vane attenuator, W. Larson, IEEE Trans. Instr. Meas. IM-12, No. 2, 50-55 (Sept. 1963).

The radio thermal noise properties of the lower atmosphere, B. R. Bean, Program and Digest 1963 IEEE Prof. Group. Antennas and Propagation Symp. Space Telecommunications, July 9-11, 1963, Boulder, Colo., pp. 30-31 (1963).

* Publications for which a price is indicated are available by purchase from the Superintendent of Documents, U.S. Government Printing Office, Washington, D.C. 20402 (foreign postage, one-fourth additional). Reprints from outside journals and the NBS Journal of Research may often be obtained directly from the authors. 